\title{
Article
}

\section{An Axiology of Residual Green Urban Areas}

\author{
Maria Rosa Trovato (1)
}

check for updates

Citation: Trovato, M.R. An Axiology of Residual Green Urban Areas. Environments 2021, 8, 53. https:// doi.org/10.3390/environments8060053

Academic Editor: Yu-Pin Lin

Received: 22 April 2021

Accepted: 29 May 2021

Published: 4 June 2021

Publisher's Note: MDPI stays neutral with regard to jurisdictional claims in published maps and institutional affiliations.

Copyright: (C) 2021 by the author. Licensee MDPI, Basel, Switzerland. This article is an open access article distributed under the terms and conditions of the Creative Commons Attribution (CC BY) license (https:// creativecommons.org/licenses/by/ $4.0 /)$.
Department of Civil Engineering and Architecture, University of Catania, 95124 Catania, Italy; mrtrovato@dica.unict.it; Tel.: +39-333-436-8621

\begin{abstract}
Our cities are often characterised by a complex, ungrammatical articulation of spaces, volumes, intended uses, and values. The residual green urban areas are representative of a low level or absence of order, but above all, of functions and values. The study proposes a new methodological and operational approach to the rehabilitation of green residual urban areas, participatory type that can generate a new order between values, functions and actors, to mediate private and public needs, to promote new forms of responsibility and thus to implement some of the priority objectives set out in the 2030 Agenda. The operational tools supporting the approach are the Contingent Valuation Method (CVM), public and private partnership (PPP) and crowdfunding. This approach supported the selection of the project and the creation of a budget with public and private funding to support the participatory rehabilitation of a residual green urban area in the municipality of Acireale. The amount of funding identified largely covers rehabilitation costs. The issue of the quality and quantity of urban greenery is crucial for the sustainability and resilience of cities to climate change. Rehabilitation of remaining urban green areas is an opportunity to meet the new needs of green areas, supporting communities in this new challenge.
\end{abstract}

Keywords: ecosystem services; CVM; Agenda 2030; placemaking; PPP; crowdfunding; natural capital; social capital; urban resilience; urban green spaces

\section{Introduction}

The urban fabric of our cities is often marked by a complex and grammatically incorrect articulation of the spaces, volumes, functions, relationships, and values that combine to create an urban landscape that is not able to communicate and inform, and that is not capable of reproducing itself. An urban landscape which has no rules, or one that results from exceptions or lack of implementation of rules, is often characterised by asymmetries that are generated by the absence or inappropriate planning and management, or by the absence or reduced perception of values [1-5]. In such a scenario, the planning process must be aimed at defining a new order for the city system. This new order can be defined on the basis of a new structure of systemic communication among the sub-urban systems [6,7]. In this respect, the city should be thought of as a dissipative structure. The city as a dissipative structure [8] can have a new development only if, on one side, its physical, functional, energetic, informational, and value entropy is reduced (summary of the interactions of other forms of systemic entropy) and, on the other, its ability to produce neg-entropically is increased. A neg-entropic development of the city is the only one capable of generating a new harmonious order on the basis of new or unspoken values and functions [9-12]. Among the sub-urban systems, that of urban green is today often manifested in a greater vulnerability or lesser ability to reproduce. The role of urban green is closely connected to the principle of urban sustainability, being the expression of sustainability in three basic dimensions of development i.e., economic, social, and environmental, and the satisfaction of the basic principles of sustainability: economic efficiency, social equity, and environmental integrity [13-16]. Sustainable development should be understood not only on a global level (Rio de Janeiro, 1992) [17], but also and especially on a local level. In the thematic strategy on the urban environment (COM2005/718) [18], the European Commission recognises 
the crucial role that cities have for achieving sustainable development and the targets established by the Lisbon Strategy (2nd European Conference on Sustainable Cities, Lisbon 1996), and states the role that the principles of conservation of biodiversity, the soil sealing and the containment of land-use planning in the context of sustainable development have in the implementation of policies promoting integrated urban sustainability [19-21]. These principles that were already present in the Agenda 21 programme (Rio de Janeiro, 1992) are confirmed in the Charter of European Cities and Towns towards Sustainability (Aalborg Charter, Alborg 1994, 1st European Conference on Sustainable Cities) [22], and the Aalborg +10 (or the Aalborg Commitments, 2004) [23]. Administrations adhering to the Aalborg Charter have recognised that natural capital (atmosphere, soil, water, and forests) is to be considered as a limiting factor for economic development of the city and have recognised the spread of the city's green areas as the primary index of civilisation and of the urban liveability of realities, and as such they must be protected and increased [24-29].

Several other agreements have been signed after that, such as the Leipzig Charter in 2007, the ICLEI network plan [30] in 2008 and the C40 or the World Sustainable Capitals in 2010. Meanwhile, the Covenant of Mayors (2008) is representing the mainstream European movement involving local authorities, voluntarily committing to increase energy efficiency and use of renewable energy sources in their territories to meet and exceed the European Union $20 \% \mathrm{CO}_{2}$ reduction objective by 2020 . The chief outcomes of this process linked to the objectives of Europe 2020 through the Toledo Declaration (EU 2010) [31] and the operationalization of the Leipzig Charter through the development of the Reference Framework for European Cities (2015) [32].

The Leipzig Charter stated that to achieve the objective of sustainable cities, an integrated approach to urban issue must be chosen, and that European structural funds should be made available for local projects embracing this integrated approach [33]. In the Lipzig Charter, the Ministers declare that "all dimensions of sustainability development should be taken into account at the same time and with the same weight. These include economic prosperity, social balance, and a healthy environment. At the same time, attention should be paid to cultural and health aspects".

European cities are described as possessing "unique cultural and architectural qualities" and functioning as "centres of knowledge" but also suffering from an array of social and environmental problems. The Charter argues that to fulfil their functions as "engine of social progress and economic growth" (Lisbon Strategy), the social balance within and among them must be maintained, cultural diversity, must be ensures, and high quality in the fields of urban design, architecture, and environment must be established.

In the Leipzig Charter, the concept of the Baukultur of a city's living environment is introduced, understood in a broad sense as "the sum of all the cultural, economic, technological, social and ecological aspects influencing the quality and process of planning and construction [33]. While the approach is viewed as "particularly important", in the preservation of architectural heritage such as historical buildings and public spaces, the Charter argues that this holistic approach should also be applied to the city as a whole and its surroundings. The Baukultur approach also stresses citizen inclusion in planning Process.

Further developments in the integrated approach were highlighted in the Toledo Declaration [31]. It highlights the role of integrated urban regeneration for the sustainable development of the city of the future. It promotes a sustainable and socially inclusive model throughout the urban environment and in all social structures of the city through the redevelopment of urban areas through the enhancement of historical resources-cultural, environmental and citizen involvement.

The Riga Declaration [34] recognised the role of urban areas in promoting sustainable economic, social, and territorial cohesion in the European Union; identified the need for coherent development between cities and non-urban territories; agreed to support policies at national or regional level that promote sustainable and integrated urban development and territorial cohesion; promoted forms of collaboration concerning sustainable and integrated 
urban development involving local communities and stakeholders (stakeholders), with the aim of providing effective urban solutions to challenges that also transcend administrative sectors and boundaries.

These principles and concepts have been taken up and extended in the 2030 Agenda for Sustainable Development, signed on 25 September 2015 by the governments of the 193 member countries of the United Nations, and approved by the UN General Assembly. It proposes 17 Sustainable Development Goals, SDGs-framed within a broader action programme consisting of 169 targets or targets, associated with them, to be achieved in the environmental, economic, social, and institutional by 2030 [35].

The objectives set for sustainable development have a global validity, concern and involve all countries and components of society, from private companies to the public sector, from civil society to information and culture operators. The 17 Goals refer to a set of important development issues that take into account in a balanced way the three dimensions of sustainable development-economic, social and ecological-and aim to end poverty, to fight against inequality, to tackle climate change, to build peaceful societies that respect human rights.

The issue of the quality and quantity of urban greenery, which refers to a local vision of sustainability and resilience of cities, is covered by the 2030 Agenda with reference to Objective 11 "Sustainable Cities and Communities", 13 "Combating climate change" and 17 "Partnership by Objectives" and some of the different targets set.

In the context of which, new methodological and operational approaches can be identified for the definition and evaluation of actions aimed at achieving them also at local level. In this context, the objectives set may be specified by some of the targets set.

"Making cities and human settlements inclusive, safe, sustainable and sustainable" means achieving by 2030, increasing inclusive and sustainable urbanisation and the shared and integrated planning and management capacity of human settlement in all countries; strengthen commitments to protect and safeguard the world's cultural and natural heritage; reduce the negative environmental impact per capita of cities, in particular as regards air quality and waste management; provide universal access to safe, inclusive and accessible public green spaces, in particular for women and children, the elderly and people with disabilities; supporting positive economic, social and environmental relations between urban, peri-urban and rural areas, strengthening national and regional development planning.

"Taking urgent measures to combat climate change and its consequences" means strengthening resilience and capacity to adapt to climate risks and natural disasters in all countries; mainstreaming policies, national strategies and plans against climate change; improving education, awareness-raising, and human and institutional capacity for climate change mitigation; adaptation, impact reduction and early warning.

"Strengthening the means of implementation and renewing the Global Partnership for Sustainable Development" is tantamount to encouraging and promoting effective partnerships between public, private, and civil society actors, building on the experience and resource accumulation strategies of the partnerships.

Some of the key elements of the 2030 Agenda are addressed in the Pact of Amsterdam [36]. It institutionalized closer cooperation between the different levels of government, from European to local, in order to overcome the immediate difficulties. To this end, the Pact establishes the European Union's Urban Agenda. In fact, the Pact does not promote cities as protagonists of urban policies at European level: It is a pact between states on cities and not an EU pact with cities.

The thematic priorities at the heart of the European Urban Agenda set by the Pact at the moment are 12: (1) Inclusion of migrants and refugees; (2) air quality; (3) urban poverty; (4) affordable housing; (5) circular economy; (6) adaptation to climate change; (7) energy transition; (8) urban mobility; (9) digital transition; (10) public procurement; (11) jobs and expertise in the local economy; (12) sustainable land use and ecological solutions-and around them, as many partnerships will be developed. 
The challenges facing European cities have changed dramatically in recent years. Issues such as digital transition, climate change, biodiversity loss, resource scarcity, migratory movements, demographic change, pandemics, social inequalities, and rapidly changing economies are at the heart of the debate.

Digital technologies are drastically transforming society, creating potential political, social, ecological, and economic benefits but also have triggered new challenges such as the digital divide, lack of privacy, security issues and market dependencies.

As the negotiations on the new Cohesion Policy are concluded, an update of the Leipzig Charter has become necessary in order to help shape the policy guidelines for cities for the next decade, indicating shared themes and approaches on which to focus the action of European and national urban policies, encouraging for the first time a direct link (Figure 1) with global objectives such as the Sustainable Development Goals.
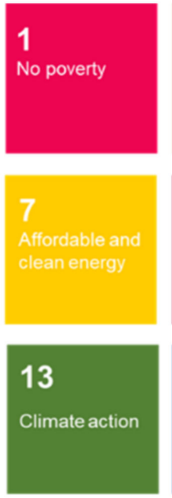
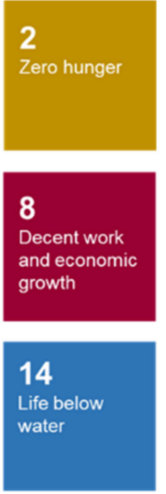
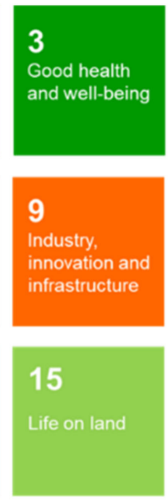
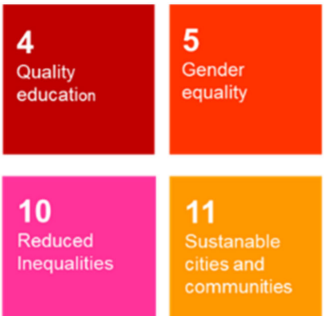

\section{6}

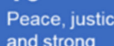

and strong

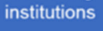

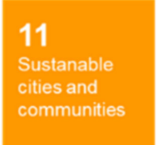

\section{7}

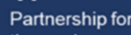

the goal
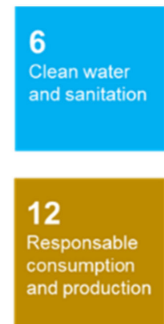

SUSTAINABLE GOALS

The New Leipzing Charter

The transformative power of cities for the common good

\begin{tabular}{cccc}
\hline DIMENSIONS OF EUROPEAN CITIES & SPATIAL LEVELS OF EUROPEAN CITIES & KEY PRINCIPLES OF GOOD URBAN GOVERNANCE \\
\cline { 1 - 1 } The just city & Neighbourhood level & Urban policy for the common good \\
The green city & Local authorities & Integrated approach \\
The productive city & Functional area & Participation and co-creation \\
Digitalisation & & Multi-level governance \\
& & Place-based approach
\end{tabular}

Figure 1. The links between the New Leipzig Charter and the Sustainable Development Goals.

The New Leipzig Charter [37] reaffirms the role of cities in the processes of creating European and national urban policies.

The basic elements highlighted by the New Leipzig Charter are the common values of European cities, from the polycentricity of urban systems to sustainable design and participatory democracy. It identifies four key features of the European city: inclusive and cohesive, ecological, productive, and connected.

The integrated and place-based approach, defined in the first version of the Charter in 2007, continues to be the guiding principles of the whole document but the angle of view widens from the disadvantaged neighbourhoods to other wider dimensions, like those of the functional areas or of the entire urban context without distinction.

The principles of multilevel governance and civic participation are combined with co-creation, co-design, and the fight against inequalities in cities.

The reference to the common good and the public interest introduced by the new Leipzig Charter emphasises the need for good and sustainable governance by local administrations acting in the common interest. It introduces a set of tools to support cities in overcoming some challenges such as housing, attractiveness for businesses, land use and 
environmental sustainability. In addition, the New Leipzig Charter highlights the need to formulate strong national urban policies and secure funding for urban development.

Once an agreement has been reached on both its new long-term EU budget and the recovery plan from the COVID-19 crisis, the New Leipzig Charter is a reference point for guiding European cities towards a new era of sustainability, resilience, and inclusivity. At the beginning of 2020, in setting its priorities, the President of the European Commission Ursula von der Leyen put the European Green Deal first, which is the EU's new growth strategy for achieving climate neutrality by 2050.

All EU policies must comply with the principles and objectives of this strategy. The only possible future is one of respect for the environment, and cities are essential to achieving this goal. The New Leipzig Charter is a reference point for the future development of European cities.

The Next Generation EU, the instrument that should enable us to overcome the dramatic economic and social consequences of the COVID-19 pandemic, is very important to implement many of the transformations needed to promote sustainable, inclusive, and resilient cities.

Within the framework of the principles of sustainability and resilience, the objectives set out in the 2030 Agenda and the guidelines set out in the New Leipzig Charter, urban residual green areas or marginal green areas can play an important role.

In particular, the term residual green urban areas refer to areas of spontaneous green consisting of portions of former agricultural areas or portions of building areas that have remained blocked in the urban fabric. They are still green areas, although uncultivated and left to total abandonment.

They are residual or marginal areas because they represent parts of the urban fabric that have not been urbanised, not planned, do not play a role in the context of urban areas in general. Their original intended use is incompatible with their current status, as they can no longer be used for agriculture or built up.

Therefore, the remaining areas in the urban fabric are, in many cases, green spaces that are closed between the urbanised areas or marginal areas of urban development. They have been produced by failed or partial urbanisation, by expropriation for public utilities that were never realised or, if they were realised, were not accompanied by the transformations envisaged by the planning instruments, by real estate speculation, or by the difficulty of managing them encountered by private individuals. These areas often become degraded and dangerous places for communities, having become marginalised by the dominance of the other sub-urban systems and relegated to a marginal status in terms of values and functions [38-42]. The residual areas, if properly perceived in terms of values and planned and managed, can become a regulatory element of urban form and of the relationships between subjects and urban values [43-45]. Today there are new tools of planning and management, new forms of partnership between public, private and community spheres, and new ways of funding that can support the rehabilitation of these areas [46-49].

In this regard, the study proposes a new methodological and operational approach to the rehabilitation of residual green urban areas, participatory type that can generate a new order between values, functions, and actors, to mediate private and public needs, and to promote new forms of responsibility and thus to implement some of the priority objectives set out in the 2030 Agenda.

The paper is organised in the following sections:

- Section 2 presents the theoretical and methodological approach to support participatory planning of residual green urban areas.

- Section 3 introduces the case study of two residual green urban areas in the municipality of Acireale;

- Section 4 reports and discusses the results;

- Section 5 proposes some reflections on the new methodological and operational approach to the rehabilitation of residual green urban areas a synthesis of the results and identifies the lines of future development of this research. 


\section{Methods}

The new methodological approach to the rehabilitation of residual or marginal areas to turn them into urban green areas can be considered as a synthesis of several theoretical approaches and tools. In this regard, for better understanding, the elements that most characterise the definition of this proposed approach are detailed below (Figure 2).

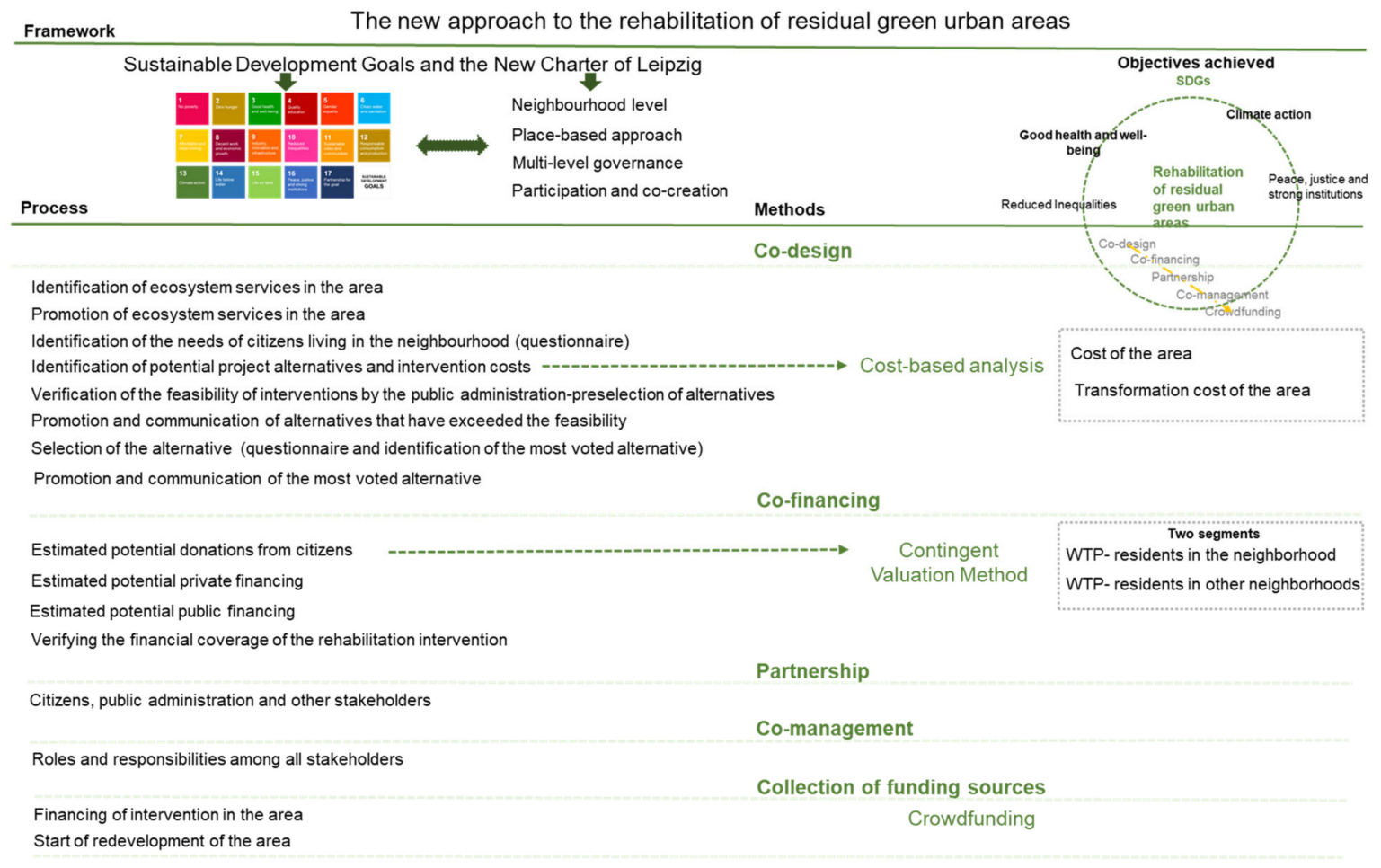

Figure 2. Flowchart-steps of research project.

\subsection{The Ecosystem Services Approach to Residual Green Urban Areas}

The classic approach to urban green is usually quantitative or at least typological: it is designed to ensure compliance with the urban standards that are laid down in national legislation (Ministerial Decree No. 1444/68) [50]. Under this approach, it is essential to quantify the supply of urban greenery in relation to the number of settled inhabitants, namely the green areas per inhabitant.

It is; however, of little significance to qualify the function of the natural capital of support for the sustainability [51]. To identify the actual functional and value dimensions of urban green, it is more appropriate to promote an integrated approach, aimed at the quantitative and qualitative identification of the flow of services and functions that are produced. The identification of the services and functions that are supported by the urban green are instrumental to assess its direct or indirect contribution to the sustainability and quality of life. In this regard it is important to identify what the benefits produced from it are, and how it is perceived by citizens. The values perceived by citizens and the awareness of the benefits that are offered by the urban green should be used to outline new development scenarios (design, protection, conservation, and increase of their endowment). An approach that best embodies these assumptions is that of the ecosystem services [52-56], that borrows from ecology the importance of investigating the various interactive processes and relationships that exist between the human and plant components, between built spaces and urban voids, between town and countryside, between administrators and citizens, between planner and user, and thus of all the systemic interactions between the sub-urban systems [57-59]. The concept of ecosystem provides a framework for analysing and acting on the links between people and the environment [60-64]. The "ecosystem 
approach" was approved by the Convention on Biological Diversity (CBD). The CBD states that "the ecosystem approach is a strategy for the integrated management of land, water and living resources that promotes conservation and sustainable use in a fair way". This approach highlights the participation of humans in many ecosystems.

Ecosystem services, as defined by the Millennium Ecosystem Assessment (MA), (2005) [65], are "the multiple benefits provided by ecosystems to mankind".

The Millennium Ecosystem Assessment describes four categories of ecosystem services (Figure 3):

- Life support (such as nutrient cycle, soil formation and primary production);

- Supply (such as food production, drinking water, materials or fuel);

- Regulation (such as regulating the climate and tides, water purification, pollination and infestation control);

- Cultural values (including aesthetic, spiritual, educational and recreational).

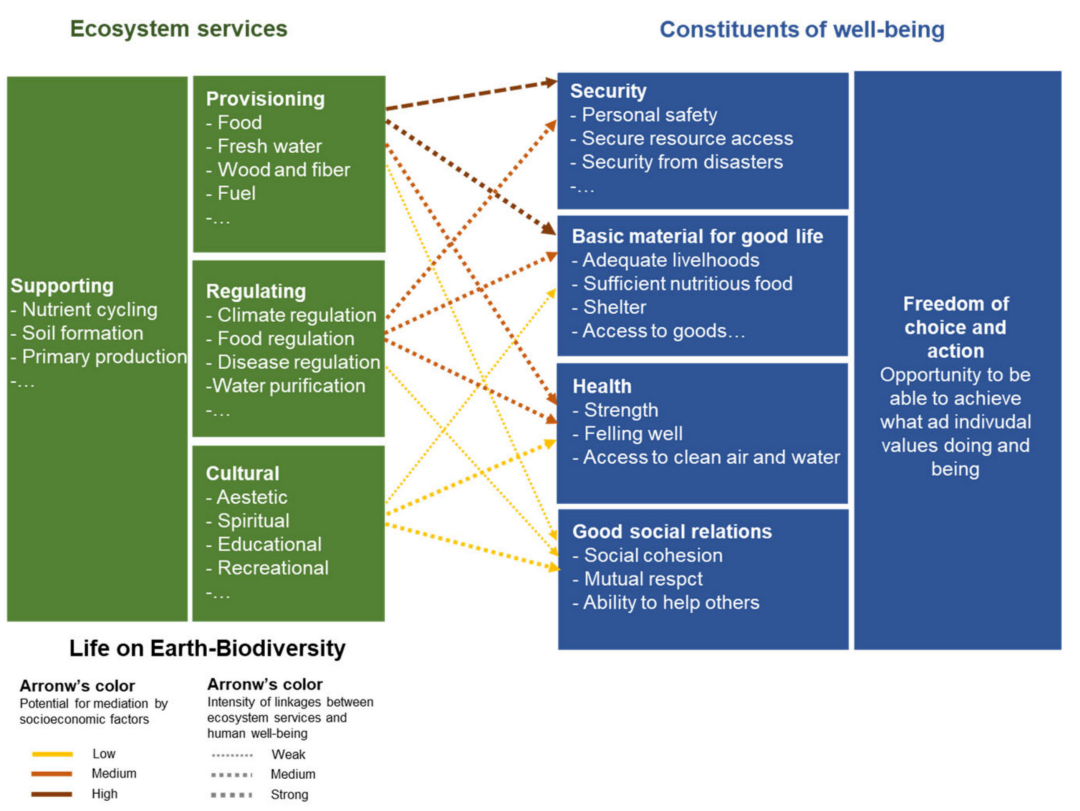

Figure 3. Linkages between ecosystem services and human well-being (our processing based on Millennium Ecosystem Assessment (MA) [65]).

The theory of ecosystem services is adopted to translate in a clear way the contribution of the urban green to the sustainability of the "city system" (i.e., identifying the functions that the green performs and the services that it produces for increasing the quality of the environment and the society) [66-72]. The ecosystem services offered by green areas and thus by rehabilitated residual green urban areas that are intended for this use are: An environmental ecological function; a health and hygiene function; a protective function; a social and recreational function; a cultural and didactic function; and an architectural aesthetic function.

The theoretical approach of reference for the determination of benefits and co-benefit generated by actions on natural capital is that of the total economic value (TEV) [73-75].

Among the methods presented in the literature for the monetary evaluation of the benefits produced by environmental resources to the community, it is possible to recall those based on demand and aimed at estimating the consumer surplus [76,77], indirect methods based on real behaviour (Hedonic price, Travel Cost Method) [78-81], and direct methods based on hypothetical behaviour (Contingent Valuation, Choice Experiments) [82-84]. The former relate to the methods of the preferences detected, the latter to those of the preferences declared. In this case we will use the Contingent Valuation for the determination of benefits produced by the green area. 


\subsubsection{Contingent Valuation Method (CVM)}

The CVM is based on the direct survey, often used in Experimental Economy and particularly useful for the evaluation of resources, goods, services and objects of cultural heritage whose value even if they had a market, would not be significantly represented by its prices [85-87], having a decisive social, cultural and environmental connotation, an ethical nature and an inter-temporal dimension, which cannot be captured by the system of individual preferences, let alone can, these goods be efficiently allocated by the market [88-90].

The CVM was defined by Mitchell and Carson [91] as follows: "The CVM method uses survey questions to elicit people's preferences for public goods by finding out what they are willing to pay for specified improvements in them. The method thus aims at eliciting their willingness to pay (WTP) in euro amounts. It circumvents the absence of markets for public goods by presenting consumers with hypothetical markets in which they can buy the good in question. The hypothetical market may be modelled after either a private goods' market or a political market. Because the elicited WTP values are contingent upon the hypothetical market described to the respondents, this approach came to be called the contingent valuation method".

The first application of the CVM was published in 1947, published in the Journal of Farms Economics by Ciriacy-Wantrup (Ciriacy-Wantrup 1947) [92], to follow other applications that were proposed by the Executive Order Reagan 12291, introduced in 1981 by CERCLA (Comprehensive Environmental Response, Compensation, and Liability Act) in 1989 [93] and in the damage assessment of the Exxon Valdez Oil Spill, in 1992 [94].

Subsequently, the NOAA (National Oceanic and Atmospheric Administration) panel developed and formalized guidelines for CVM as a tool for measuring and validating such monetary measures to conduct cost-benefit analysis and the assessment of damage costs. These guidelines can be summarised in six key recommendations [95]:

- Should rely on face-to-face interviews rather than telephone interviews;

- Should elicit (extract) the respondent's WTP to prevent a future incident instead of the WTA from an incident that has already occurred;

- Should use a dichotomous choice elicitation format, meaning that respondents should be invited to express how they would vote, that is, whether they are in favour of or against a change in environmental quality;

- Should contain an accurate and comprehensible description of the programme or policy under consideration and its benefits in each of the scenarios;

- Should include asset replacement reminders to those under consideration and their relative budgets;

- Should include a follow-up section at the end of the questionnaire to ensure that respondents understood (or not) the choice that was requested of them.

The CVM is a direct method that allows the evaluation of public or mixed goods, without market based on the recognition of the preferences expressed directly by the consumer, current or potential $[96,97]$ and then be used for the estimation of TEV, making it particularly suitable for the evaluation of benefits in cost-benefit analysis [98].

This method assesses willingness to pay (WTP) or to accept (WTA) in line with a certain offer of a public good [99].

For the implementation of the CVM, a reference market is simulated for the estimated asset, and a statistically significant sample is selected that represents the population potentially interested in that asset. Within the market thus configured, the willingness to pay (WTP) or to accept (WTA) a sum of money for the good or service is detected through direct interviews [100-102].

The definition of the structure of the questionnaire is the fundamental moment in the development of the evaluation, as it must be able to induce the respondents to declare their real preferences. The questionnaire consists of three sections: 
1. The first describes the effects of the intervention or policy, the contingent market and the conditions of access to the works or benefits of the policy (introductory section);

2. In the second, the respondent is invited to declare his WTP for access to the work or the results of the policy described (evaluation section);

3. The third section collects socio-demographic information on respondents that are useful to characterise their profile, understand the reasons for the declared WTP and verify the understanding of the survey and the evaluation request (final section).

The detection of the WTP can take place operationally through two main modes:

- Noting the maximum WTP of the interviewee declared on the basis of values suggested in the questionnaire administered (close ended question), as suggested by the NOAA Panel, or with the technique single-bounded discrete choice, where a single figure is proposed;

- Noting the maximum WTP declared by the interviewee who is called to set a specific figure (open ended question) or with the bidding game format technique, which simulates a sort of auction.

In this case, the close-ended response format was used, which offered the advantage of administering the questionnaire without direct interaction, reaching a high number of respondents who had the opportunity to choose between some suggested values, without prejudice to the possibility of showing a willingness to pay nothing. The questionnaire was administered via a digital platform, but also by presence.

In this study the respondent was asked to declare his first preference based on a set of values presented in the final structure of the questionnaire, obtained from a preliminary phase of analysis and verification conducted by administering some questionnaires constructed using the multiple-bounded discrete choice technique. The final structure of the questionnaire reduces the starting point bias problem, because the interviewee is called upon to express himself on a set of values resulting from the individual preferences of the sample of population interviewed at the preliminary stage and not by a single value fixed a priori.

\subsubsection{Sample Validation and Correlations between Variables}

The sample size both in the case of the detection of preferences of clarified and finalized to CVM can be validated with reference to causal samples using the following formula Equation (1):

$$
n=\left(u \frac{\sigma}{e}\right)^{2}
$$

where:

$n=$ number of interviews;

$u=$ standardized variable (measures the degree of certainty that the sample correctly represents the population within a defined margin of error, the probability typically associated with estimates can be assumed to be $90 \%$ or $95 \%$, which corresponds to respectively variable $u_{0.90}=1.65$ o $u_{0.95}=1.95$ );

$e=$ maximum error: deviation of the estimated value deemed acceptable in relation to the actual value depending on the type of estimate and the expected value;

$\sigma=$ standard deviation of the dependent variable.

To assess the correlations between WTP and the socio-economic variables considered a $\chi^{2}$ test statistical independence test will be applied.

It allows to verify if there is an association between two variables: With the use of contingency tables, the difference between the observed frequencies and the expected frequencies is calculated, or those that would be observed if there were no association between the two variables.

\subsection{The Partnerships for the Requalification of Residual Green Urban Areas}

A basic principle for governance, which was set by the European Commission in the White Paper on governance, is that of participation. The quality, relevance, and effective- 
ness of the policies of the European Union depend on extensive participation. The objective of the promotion of good governance based on participation has been confirmed in Europe 2020, the strategic document for smart, sustainable, and inclusive growth of the EU. This approach has promoted a change in the approach to planning, which must become more sustainable, participatory, and inclusive. Today, if on the one hand the European and national legislation should promote this approach, on the other hand communities, after years of apparent indifference or neutrality, assume a new awareness, a new perception of their role, no longer marginal but active [103-105]. Today's communities can be supported in the performance of their right to participation by new technological tools, such as the social networks, that have increasingly become tools to support sharing and social-political participation, but also by new governance and partnerships models. The partnership, in general, arises from the confrontation between different parts (public or private, economic, and social forces), and is aimed at the implementation of measures to support the economic development and social integration of the territory. Among the different forms of partnership, one may recall public and private partnerships (PPPs) as a form of cooperation between public and private entities directed at the financing, building, and operating of new infrastructure or provision of services of public interest (EU Commission Communication 30 April 2004, COM 2004 327) [106]. Communities, in the context of developments in governance models and with the support of new technologies, can even promote and guide the planning process of a public infrastructure, thus ushering in a new form of partnership between communities, public bodies, and private entities, that can be called Civic-Public-Private Partnerships. The PPPC has contractual arrangements between the parties concerned like the classic PPP. A partnership of this type can find support in financing channels different from those traditionally used in the PPP.

\subsection{The Instrument for Financing the Rehabilitation of Residual Green Urban Areas}

A possible financing instrument to support the rehabilitation of residual green urban areas is crowdfunding. This is a practice of microfinance from below that mobilises people and resources. The platform that allows the meeting and collaboration of the involved parties in a crowdfunding project is the web. According to the Framework for European Crowdfunding, "the rise of crowdfunding in the last decade derives from the proliferation and the establishment of web services and mobile applications, conditions that allow entrepreneurs, businesses, and creative people of all kinds to be able to converse with the crowd to obtain ideas, raise money, and solicit input on the product or service that they intend to propose". In practice, different types of crowdfunding exist: For reward (reward based); donation (donation based); civic equity (equity based); loans (lending based); and hybrid models based on two or more of these. Among all the European countries, only Italy has adopted specific regulations for equity crowdfunding (i.e., some rules introduced by Legislative Decree No. 179/2012 (converted into law on 17 December 2012, No. 221) [107] entitled "Further urgent measures for growth of the country" (and also known as "Decree for growth bis", and as the Regulation of 26 June 2013 with the Consob)) [108]. Here a deeper consideration is required, given the theme of this study, of civic crowdfunding, which is one of the types of fundraising from the bottom that has had the greatest success. It can be described as the collective financing of public works and projects that, being beyond the budget of the institution or involved administration, is made by citizens, organisations, and private companies, sometimes in match funding with that administration. It aims to overcome the separation between the private, public, and enterprise spheres in view of a good and common welfare. It can be considered as the product of the affirmation of a civic economy that is based on social values and objectives, that uses deep partnership approaches to development, production, knowledge sharing, and financing, and that generates assets, common services, and infrastructure in ways that cannot be implemented by either the State or the market economy. The number of institutional actors who are using this instrument to finance public works and restoration activities in urban contexts is growing strongly. The literature for crowdfunding proposes the use of an integrated 
platform of crowdsourcing, crowd validation, and crowdfunding [108-110] (i.e., a crowd sourcing, validation, and funding system).

\subsection{The New Approach to the Requalification of Residual Green Urban Areas}

The new approach to the requalification of residual green urban areas intended for urban green spaces can be synthesised in the phases reported in Table 1.

Table 1. The new approach to the rehabilitation of residual green urban areas intended for urban green spaces.

The New Approach to the Rehabilitation of Residual Green Urban Areas Intended for Urban Green Spaces

1. Information and citizen awareness campaign promoted by a group of citizens or associations, or by the public administration.

(Preliminary informative phase)

2. Survey sample aimed at identifying the needs of citizens.

(Needs analysis phase)

3. Identification of some alternatives (costs, benefits, and potential stakeholders).

(Preliminary design phase)

4. Verification of some potential project alternatives by the public administration.

(Preliminary verification phase)

5. Information campaign for the promotion of the potential project alternatives.

(Raising awareness of potential project alternatives phase)

6. Sample survey aimed at identifying the feedback for potential project alternatives. (Analysis of adhesion/dissent and integration phase)

7. Identification of the alternative. (Selection phase)

8. Drafting of a membership scheme to support the partnership (PPP or CPPP).

9. Communication campaign of selected project with off-line and on-line methodologies.

(Promotion of project phase)

10. Analysis of accessions to the project for financing.

(Adhesion analysis and WTP phase)

11. Identification of the mix of funding sources and share of the funding from crowdfunding.

12. Launching of the crowdfunding with the help of the web platform.

(Funding research phase)

13. Launching the administrative procedure for the realisation of the project that has obtained financial coverage by crowdfunding.

(Formalisation of the partnership and realisation of the works phase)

\section{Materials}

The study investigates the recovery of two residual green urban areas, namely green spaces that have been closed between the urbanised areas in the City of Acireale.

Acireale is an Italian municipality of 50,744 inhabitants of the metropolitan city of Catania in Sicily.

One of the two small part-built areas is located near the historic centre (Area 1). It has a surface area of 2679 square metres and is bounded on one side by Via S. Vigo, an important thoroughfare of the city, and on the other side by the neighbourhood's street of Via Mandorle, furthermore it is located close to the former IPAB Pennisi Alessi di Acireale complex (a social welfare institution) that was closed down (pursuant to Article 34, paragraph 2, of Regional Law No. 22/1986) [111] and which has been passed to the municipality of Acireale. The second not far from the first, is constituted by an empty space in an urbanised area within the historic centre, and can be accessed by a neighbourhood street, Via Maddem (Area 2). It comprises an area of 15,210 square metres (Figure 4). 


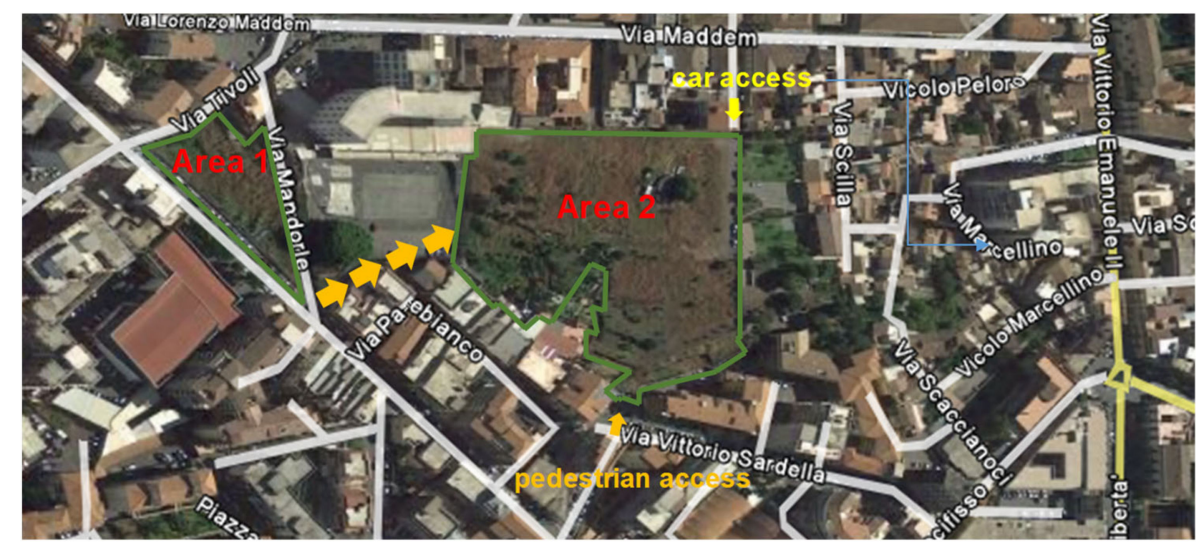

Figure 4. Location of Areas 1 and 2.

The two areas fall within the neighbourhoods of San Martino, San Michele, and Piazza Carmine, and marginally within Mandorle, Tupparello, and Stazione Vecchia. They have an average population compared to that of the other districts of Acireale centre (Figure 5).

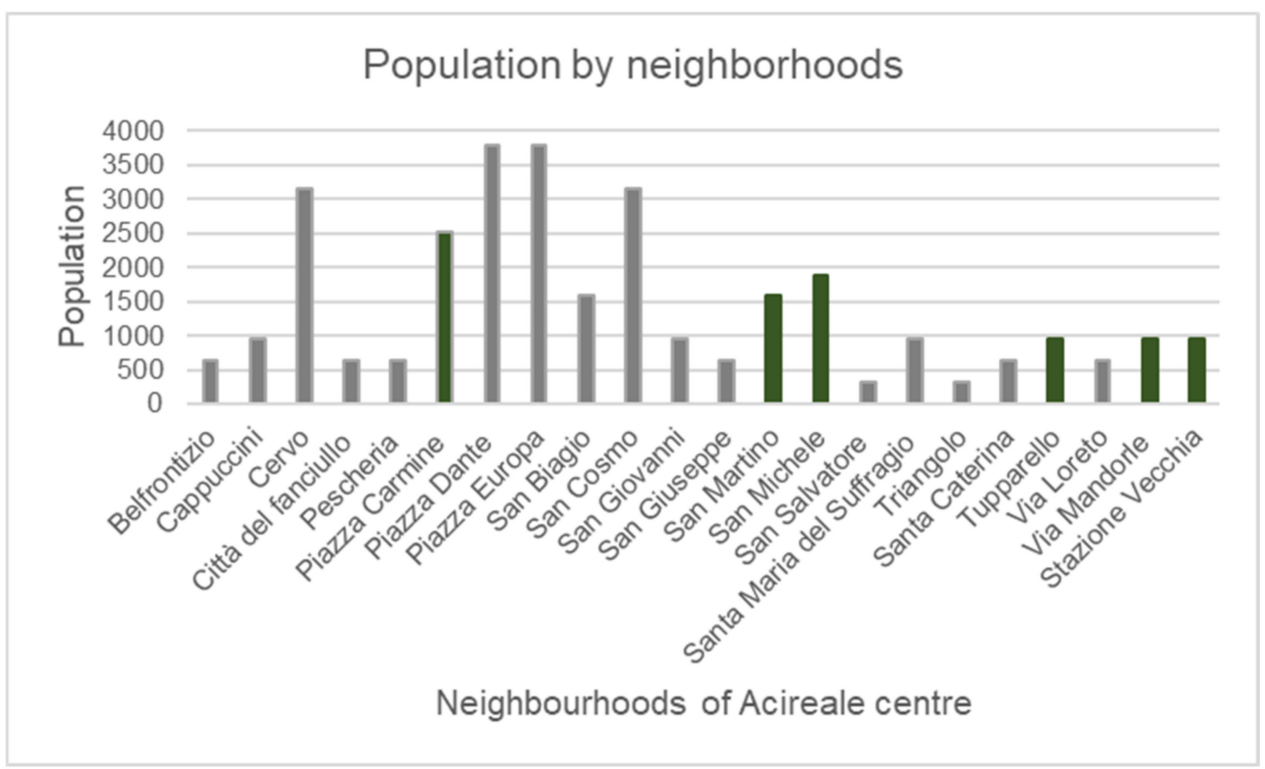

Figure 5. Distribution of population by neighbourhoods of Acireale centre (histograms in green highlight the population of the neighbourhoods directly involved in the project, those in grey the population in the other neighbourhoods of Acireale centre).

The forecast of the new general urban development plan (approved by the Decree of 4 November 2003, G.U.R.S.N. No. 54 of 12/12/2003, and the Decree of 18 January 2005, G.U.R.S.N. No. 8 of 25/02/2005) designated these two areas as public green areas. Unfortunately, these areas have never been acquired and transformed by the local authority, in a context in which the minimum provision of urban planning standards relating to the public green component is insufficient. Today the administration is working on the preparation of a new general urban development plan because the bonds have expired, and it is likely that the administration will confirm the current designation, since the areas where urban green can be allocated are insufficient and they must respect the legal constraints in force (Table 2). 
Table 2. The current and potential needs for green areas in the neighbourhoods covered by the analysis.

\begin{tabular}{lc}
\hline \multicolumn{1}{c}{ Neighbourhoods Interested } & Population by Neighbourhoods \\
\hline San Martino & 1581 \\
San Michele & 1897 \\
Piazza Carmine & 2530 \\
Mandorle & 949 \\
Tupparello & 949 \\
Stazione Vecchia & 949 \\
\hline Total population neighbourhoods & 8854 \\
\hline Urban standard-public green areas & Square meters per inhabitant \\
(Ministerial Decree No. 1444/1968) & 9 \\
\hline $\begin{array}{l}\text { Current provision of green areas in } \\
\text { neighbourhoods interested in the analysis }\end{array}$ & 0 \\
$\begin{array}{l}\text { Current deficit provision of green areas in } \\
\text { neighbourhoods covered in the analysis }\end{array}$ & 9 \\
\hline $\begin{array}{l}\text { New provision of green areas in } \\
\text { neighbourhoods covered in the analysis } \\
\text { New deficit of the new provision of green areas } \\
\text { in neighbourhoods covered in the analysis }\end{array}$ & 2.02 \\
\hline
\end{tabular}

The first of the two areas are characterised today by the almost total absence of vegetation, as it was originally intended for the cultivation of grapes, and for many years has been affected by summer fires due to the lack of maintenance of the natural vegetation. The second of the areas has meagre vegetation, represented mostly by olive and citrus trees.

\section{Results}

The resident population in this portion of the city noted the lack of green spaces and/or equipped green areas, of play areas for children, and of spaces for the elderly. The debate, which originated in a totally random way in a parish context with the exchange of a few words in a few neighbourhood meetings places such as bars and neighbourhood squares, has prompted citizens to develop a new awareness of the lack of spaces allocated to those needs through a failure and partial urbanisation that had been ignored for too long. The perception and the values that this community attributes to these areas, under the pressure of this new awareness, have profoundly altered. Indeed, they are no longer perceived as derelict areas with low or constant values, or degraded areas with denied values due to fires or trash accumulation but are instead perceived as areas of missed opportunity and unspoken value. The process of acquiring this new awareness, in terms of perception and values, has prompted the community to rebel against this way of managing assets that have public importance, even if they are private property.

\section{A. Co-Design Phase}

The community wants to take on a new role, no longer marginal but active, and so a few subjects, moving from an initial phase of word of mouth, began to turn into a cohesive group that goes so far as to define an establishment that goes beyond a neighbourhood committee as the areas affect more than just one neighbourhood [112-118]. This representative group, made up of ordinary people, has become the promoter and intermediary with the administration, and is looking to the university for collaboration. Thus, a group of citizens, in cooperation with a research group, has promoted and launched the information and awareness campaign for the neighbourhood citizens.

\section{A.1. Identification of Ecosystem Services in the Area}

They have preliminarily identified the ecosystem services [119-121] for urban green residual areas that is the subject of this study, focussing on: the mitigation of air and noise pollution (namely the reduction of pollutants in the atmosphere since one of the areas is 
near to a road with intense traffic, and a reduction of noise for the school facilities, since there is a nearby educational facility with a primary school and a secondary school located in the IPAB Pennisi Alessi di Acireale complex); the hygienic and health function (for the psychological benefits produced by the relaxing view of a green area); protection of the soil (reduction of waterproofed surface, recovery of marginal and abandoned land, collection of rainwater that often floods the lower part of San Vigo street and the Stazione Vecchia): the conservation and enhancement of biodiversity; the improvement of the aesthetic image of the city; the development of recreational functions and free sports facilities in areas not equipped or semi-equipped; and the development of naturalistic education and sociohistorical and environmental culture (for the proximity to the school facilities on the San Vigo street and those located in the IPAB Alessi Pennisi complex of Acireale).

\section{A.2. Promotion of Ecosystem Services in the Area}

A small communication campaign was organised to promote the results of the analysis aimed at identifying the ecosystem services produced by the residual green urban areas covered by this study. This campaign was conducted with the help of movies, that is, short presentations that can be viewed online and in parishes, and leaflets and posters made available in parishes and commercial premises.

\section{A.3. Identification of the Needs of Citizens Living in the Neighbourhood}

Subsequently, a questionnaire was administered to identify the needs of citizens, and to gauge the level of support from citizens who are directly involved in the initiative.

In particular, this phase is instrumental for the generation of potential rehabilitation alternatives for the areas concerned.

The questionnaire was administered in the physical places previously mentioned and online.

This survey was also been extended to citizens living in other neighbourhoods of the city of Acireale with the help of social networks and some potential stakeholders.

\section{A.4. Identification of Potential Project Alternatives and Intervention Costs}

Based on the results of the questionnaires, some project alternatives have been identified for the two areas, along with the set of stakeholders who are affected by them:

Rehabilitation projects for Area 1:

1. Equipped green area (rainwater collection system).

2. Equipped green area (rainwater collection system) + theatre.

3. Equipped green area (rainwater collection system) + civic and teaching garden.

Rehabilitation projects for Area 2:

1. Equipped green area without connection to Area 1.

2. Equipped green area with connection to Area 1.

3. Equipped green area with connection to Area $1+$ internal square.

4. Equipped green area with connection to Area $1+$ internal square + dog play area.

For Areas 1 and 2, the acquisition costs of the areas and the transformation costs for the different selected alternatives were estimated in advance.

The market investigation that was conducted for urban residual areas with similar characteristics identified a range of minimum and maximum values for this area type of between $€ 10$ and $€ 16$ per $\mathrm{m}^{2}$ [122-126]. The value of Area 1, which has an urban constraint to public green, was estimated at $€ 26,790$. The value of Area 2, which also has an urban constraint to public green, has been estimated at $€ 152,100$. Transformation costs were estimated for the different project alternatives for the two Areas (Table 3) to support the identification of the most cost-sustainable project. 
A.5. Verification of the Feasibility of Interventions by the Public Administration-Preselection of Alternatives

Table 3. Transformation costs for the different project alternatives of the two areas.

\begin{tabular}{lc}
\hline Transformation cost of the Area 1 & \\
\hline 1. Equipped green area (rainwater collection system) & $€ 145,387.67$ \\
$\begin{array}{l}\text { 2. Equipped green area (rainwater collection system) + theatre } \\
\text { 3. Equipped green area (rainwater collection system) + civic and }\end{array}$ & $€ 226,158.59$ \\
teaching garden & $€ 161,541.85$ \\
\hline Transformation cost of the Area 2 & $€ 872,325.99$ \\
\hline 1. Equipped green area without connection to Area 1 & $€ 959,558.59$ \\
2. Equipped green area with connection to Area 1 & $€ 1,247,426.17$ \\
3. Equipped green area with connection to Area 1+ internal square & $€ 1,295,404.10$ \\
4. Equipped green area with connection to Area 1+ internal square & \\
+ dog play area & \\
\hline
\end{tabular}

The project alternatives were subjected to a preliminary verification by the administration, which has raised some criticism about the provision of interventions for Area 2. This area, in fact, has a greater extension than Area 1, as well as a more fragmented system of ownership than the first, being the property of three different subjects.

The municipal administration, in fact, has not had and does not now have the necessary financial means to acquire such a large area, and has postponed its planning until the new general urban development plan that is in preparation, hoping that the acquisition and transformation may be made with the aid of an equalising practice.

On the basis of the explicit request of the municipal administration, the alternatives concerning Area 2 have been excluded from the participatory design and selection process.

The results of the pre-selection by the municipal administration were communicated through the channels mentioned above, in order to inform all stakeholders of the exclusion of Area 2 from the co-design process for the neighbourhoods concerned.

\section{A.6. Promotion and Communication of Project Alternatives only for Area 1}

Subsequently, a communication campaign was launched to promote the project alternatives that have passed the verification phase from the municipal administration, then only those that affected Area 1, using the same methods previously mentioned.

\section{A.7. Selection of the Project Alternative for Area 1}

This last phase was followed by a new survey campaign, again with the help of a questionnaire, instrumental in identifying the design alternative that shows the greatest support from citizens in the neighbourhoods directly concerned, for citizens living in the other neighbourhoods of Acireale and potential stakeholders.

The alternative for Area 1 that has had more membership is the one that provides for the creation of a green area equipped, supported by a rainwater collection system and including a civic and educational garden (i.e., alternative 3 ).

\section{A.8. Promotion and Communication of the Most Voted Alternative for Area 1}

Subsequently, a communication campaign was launched to inform all stakeholders of the outcome of the participatory selection. The co-design process identified alternative 3 for the redevelopment of Area 1.

\section{B. Co-Finanging Phase}

Once the participatory rehabilitation project for Area 1 was selected, the municipal administration requested a more detailed estimate of the transformation costs for Area 1 (Table 4). 
Table 4. Transformation costs of Area 1.

\begin{tabular}{lc}
\hline Transformation Cost of the Area 1 (Alternative 3) & \\
\hline Working the soil & $€ 2164.72$ \\
Rainwater collection system & $€ 54,770.19$ \\
Irrigation system & $€ 18,534.24$ \\
Planting of flowers & $€ 10,991.25$ \\
Planting of creepers & $€ 497.40$ \\
Planting of trees & $€ 3741.00$ \\
Laying of turf & $€ 5075.22$ \\
Erecting the fence and gate & $€ 11,954.80$ \\
Laying the "drainage paving" in the interior area & $€ 16,340.00$ \\
Laying the paving in the outdoor area & $€ 2401.00$ \\
LED lighting & $€ 17,917.02$ \\
Outdoor furniture & $€ 5188.95$ \\
Technical and general expenses. & $€ 11,966.06$ \\
& $3 \%$ \\
\hline Total transformation cost & $€ \mathbf{1 6 6 , 3 8 8 . 1 1}$ \\
\hline
\end{tabular}

The transformation cost of the area for under-interventions has been estimated by a bill of quantities based on the Regional Sicilian Price List [127]. The transformation cost of the area was estimated at $€ 161,542$, for caution a margin of $3 \%$ was accounted to consider the possible variations in the market price of the supplies. The total processing cost of Area 1 for alternative 3 was estimated at $€ 166,388$.

The total cost of acquisition and transformation of the area is estimated at $€ 193,178$.

B1. Estimate of Potential Donation from Citizens-WTP of Two Segments-Resident in the Neighbourhoods Involved in the Project and Resident in the Other Neighbourhoods of the City of Acireale

A new survey campaign was carried out at this stage, again with the help of a questionnaire, through which the WTP of the residents in the neighbourhoods directly affected by the project, and sympathizing citizens residing in other neighbourhoods of the city of Acireale, was taken over.

The questionnaire responses were analysed to determine a probability density function to calculate the willingness to pay of the sample of households in neighbourhoods directly involved in the project. The sample was asked to express the willingness to pay based on the selected scenario, which provides for the participation of households living in the neighbourhoods directly involved in the project of the area to crowdfunding, and then with a one-off donation. The households joined the rehabilitation project with great enthusiasm. The size of the sample of households in the neighbourhoods affected by the project compared to those of the other neighbourhoods of Acireale centre is quite large. (Figure 6).

A total of $60 \%$ of households for the Carmine and Tupparello neighborhoods, $50 \%$ for the San Michele and San Martino neighbourhoods, $40 \%$ for the Mandorle and Stazione Vecchia neighbourhoods.

A random sampling was carried out, in which every one of the populations had the same probability of being part of the sample. For a random sample to be statistically significant, it must have an appropriate size, which was evaluated based on Equation (1). 


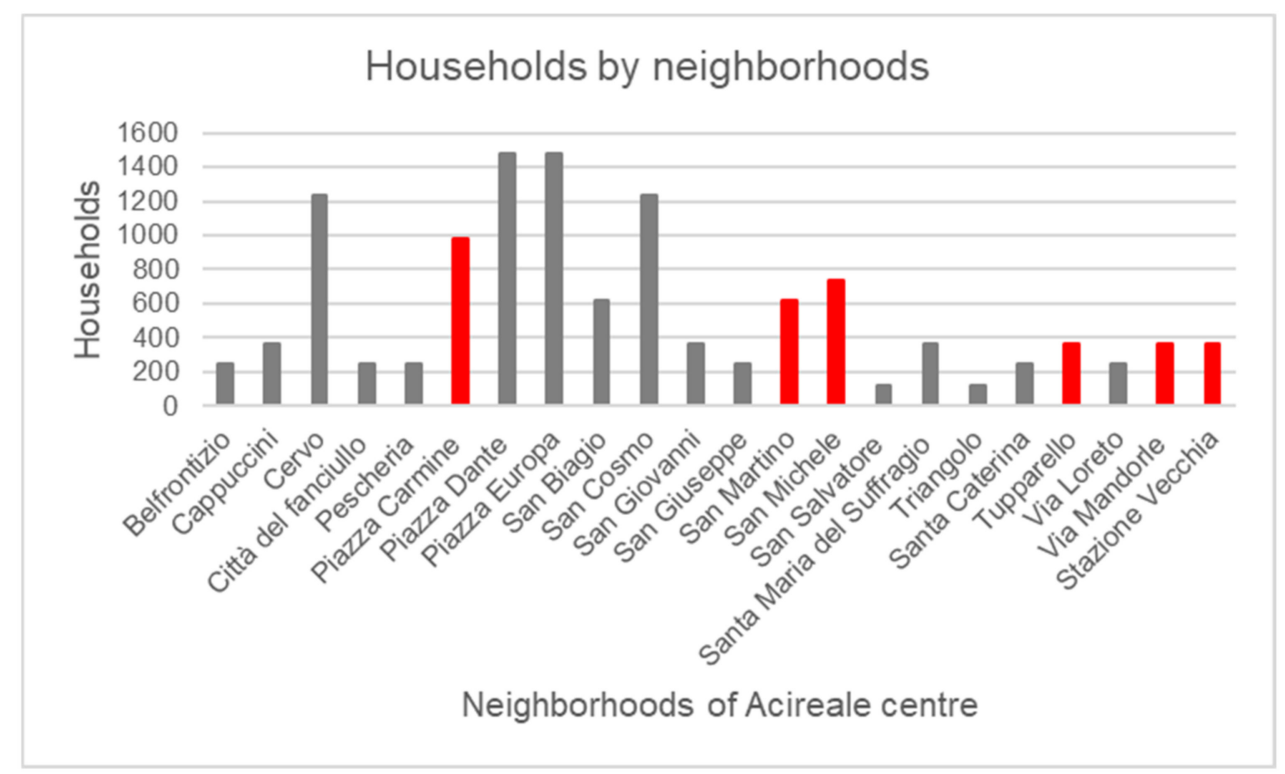

Figure 6. Distribution of households by neighbourhoods of Acireale centre (histograms in red highlight the households of the neighbourhoods directly involved in the project, those in grey the households in the other neighbourhoods of Acireale centre).

The size of the sample representative of the estimated population admitting an $e$ error of $10 \%$ of the average WTP of $53.29 €$, the standard deviation $\sigma$ of $43.12 €$, with $u=1.96$ for a probability of $95 \%$, is obtained $n$ equal to 1006 households. The sample of 3939 households is quite large and; therefore, meets the statistical verification. The $W T P_{\text {Tot }}=W T P_{\text {average }} \cdot n$. households is $209,961 €$.

To understand if there is a correlation between the ability to pay and other socioeconomic variables, the Chi square test was applied. Contingency tables were constructed for WTP-gender, age, educational qualification, employment, income, and environmental sensitivity, but in no case were any correlations found between the variables, since the null hypothesis was always confirmed.

The results of the questionnaire administer to citizens living in other neighbourhoods of the municipality of Acireale, who were asked to support the project with a symbolic donation of $€ 2$, showed a participation of $60 \%$ of households. The contribution of civic solidarity is $€ 10.194$, which however shows a good participation of citizens in co-funding to support the rehabilitation of the Area 1.

\section{B.2. Estimate of Potential Private Financing}

The acquisition cost of the area subject to the civic action is to be covered by the municipal administration and the remainder, namely about $€ 166,388$ when rounded upward, is to be financed in part by the crowdfunding and the remaining part by donations from the stakeholders who have expressed their support and economic commitment (Table 4).

It was detected for the stakeholders who had participated in the co-design process for the areas the willingness to donate a one-off contribution to a fund to be set up to support the redevelopment project of the selected Area 1.

The stakeholders, who participated in the process, are private individuals, some businesses and a bank, which have become available to finance the project with a donation. The amount of donations for the different subjects are highlighted in Table 5. 


\section{B.3. Estimated Potential Public Financing}

Table 5. The mix of private financings.

\begin{tabular}{ll}
\hline Financing Private Sector & \\
\hline Donations from the commercial sector & $€ 25,000$ \\
Donations from private individuals & $€ 12,000$ \\
Donations from banks & $€ 10,000$ \\
\hline Total financing private sector & $€ 47,000$ \\
\hline
\end{tabular}

It was detected for the municipal administration the contribution to the fund to be set up to support the redevelopment project of Area 1, which amounts to $€ 26,790$, that is equal to the cost of acquisition of the area subject to the civic action.

Verifying the financial coverage of the rehabilitation intervention

The identification of the mix of funding sources for the redevelopment of Area 1 is instrumental to verify the level of coverage of the costs of transformation and acquisition of the area.

The mix of funding sources and the verification of the coverage of redevelopment costs are highlighted in Table 6.

Table 6. The mix of funding sources for the rehabilitation of the residual area.

\begin{tabular}{|c|c|c|}
\hline \multicolumn{3}{|c|}{ Financing for the Rehabilitation Intervention } \\
\hline 1. Amount to be financed & & $€ 166,388$ \\
\hline 2. Donations from the commercial sector & & $€ 25,000$ \\
\hline 3. Donations from private individuals & & $€ 12,000$ \\
\hline 4. Donations from banks & & $€ 10,000$ \\
\hline 5. WTP potential of the sample population & To be financed by & $€ 209,961$ \\
\hline 6. Civic solidarity contribution & crowdfunding & $€ 10,194$ \\
\hline Total amount of financing & & $€ 267,155$ \\
\hline Percentage of financing covered & & $160.6 \%$ \\
\hline
\end{tabular}

The amount of funding identified largely covers rehabilitation costs. The neighbourhood communities joined the project with great enthusiasm.

Surely the population that resides in the neighbourhoods involved in the project are those who offer the most financial support, those living in other neighbourhoods have offered with a large membership, a small contribution of civic solidarity, which has great symbolic value. The budget exceeding the cost of the rehabilitation could be used to finance the maintenance of the new green area.

\section{Partnership}

The co-design process has led to the identification of a project for Area 1 that responds to the needs of the citizens of the districts concerned, which has exceeded the feasibility by technicians and the municipal administration. The phase of co-funding highlighted the financial sustainability of the intervention.

Subsequently, a membership scheme was developed between stakeholders for the creation of the partnership between the public (administration), private (commercial and banking operators or other; private donations), and the community (promoter and potential sponsors of the project). This membership scheme is instrumental in establishing roles and responsibilities among all stakeholders.

As regards the ancillary works to the Area 1 project, the municipal administration has committed: To carry out the expropriation of the area for public utility; to provide connection to the water service; to support the cost of water supply; to carry out and finance the works linking the disposal of meteoric water in the area with the public urban network. 


\section{Co-Management}

The membership scheme is the basis for the promotion of the co-management of the new green area, that is to say, of a participatory management between private and public entities. The management of the area is mostly the responsibility of the municipal administration, which will provide for the maintenance and cleaning of the area, while the neighbourhood committee and volunteers are entrusted with the opening and closing of the green area, the management of activities within the area including civic and teaching garden.

\section{E. Collection of Funding Sources}

The partnership identified the web platform on which to launch crowdfunding, in this case Meridonare was chosen. Crowdfunding was launched in November 2019, with a wide membership, larger than previously estimated. Consequently, to the constitution of the fund has been fixed the start date of rehabilitation intervention for Area 1 (i.e., for March 2020).

\section{Discussion and Conclusions}

A walk in our cities reveals the presence of residual green urban areas that are often degraded and potentially dangerous, leading one to reflect on the factors that have determined the state of these areas. It is impossible, in fact, to accept that areas that are undeveloped and guaranteed clear according to the destination specified by the planning instruments, can be considered as marginal, be excluded from the design of the city, and be devoid of value and function [128-130], at a time when the availability of urban green areas is scarce, especially in contexts in which the minimum requirement for these types of areas are not met for whole neighbourhoods and even cities in which there is an ever growing demand/need for them, and in which there is a growing awareness of the ecosystem services they provide and; therefore, of their contribution to sustainability [131]. Today the urban green sub-system manifests a greater vulnerability and a lower ability to reproduce itself.

According to a systemic approach to the city, this state seems only to depress the urban green sub-system, but it also reduces the ability of the other sub-urban systems to reproduce themselves, compromising the direction of neg-entropic development, the only possible point to respect the principles of sustainability. The enclosed residual green areas, if they are properly perceived in terms of values, and planned and managed accordingly, can become places in which to meet the needs for public green areas, to repair the communication between the sub-urban systems, to generate sustainable development, and to increase the quality of life in cities.

The issue of the quality and quantity of urban greenery is crucial in the context of sustainability and in increasing the resilience of cities to climate change that have become increasingly an emergency issue [132-135].

The rehabilitation of residual green urban areas is an opportunity to support the resilience of cities in tackling climate change-related effects, improving the well-being and integration of communities [136-138], increase the stock of green urban capital, reduce urban degradation related to the abandonment of parts of areas within cities, increase environmental awareness of communities [139-143].

Addressing this issue with a view to creating inclusive and safe cities in accordance with the approach proposed by Agenda 2030 and New Charter of Leipzig means promoting participatory planning and management of cities, based on participatory decision-making processes $[144,145]$ and partnerships between public actors, public-private and civil society.

In this perspective, the promotion of the approach of placemaking [146,147] can improve a neighbourhood, a city, as it is able to capitalize on the resources, inspiration, and potential of a local community, translating into the creation of quality public spaces that contribute to people's health, happiness, and well-being [148].

Communities can collectively reinvent public spaces, strengthening the connection between people and places they share, supported by creative models, capable of integrating physical identities, cultural and social that define a place and their continuous evolution. 
In this regard, this study has proposed a new approach to the requalification of residual green urban areas, whose main elements are: The values perceived by the community of the ecosystem services offered by residual green urban areas; the shared values, and the way in which these values enhance those of the individual; the generation of a new coordinated development between urban components that respects the principles of sustainability; the functions as a set of possible representations of values; the design and; therefore, the new order as a result of the convergence of functions that underlie the values. The proposed operational tools are: the promotion of ecosystem services offered by green areas and potentially by rehabilitated residual green areas; the analysis of the needs of citizens; the identification of their declared preferences which are instrumental for the contingent valuation and estimation of the WTP; new forms of partnership between stakeholders such as the Civic-Private-Public Partnership; a new form of management of the planning process (the community as promoter and manager); and new financing instruments such as civic crowdfunding.

The experiment carried out in the two areas has produced good results for Area 1 but poor results for Area 2. The two areas, in fact, are characterised by different dimensions and regimes of ownership, but they have the same destination in the current and potential planning forecasts, namely that of public green space. The specific characteristics of the areas of interest define a different level and a different hierarchy of roles among stakeholders. The community has more ability to promote and manage the process of acquiring and processing for Area 1, while these actions become difficult for Area 2. The process for the latter area is blocked by the municipal administration. The community, despite being aware of the importance of Area 2 for the satisfaction of their needs, which cannot only be expressed by Area 1, preferred to concentrate their forces only on the transformation of the latter, which appears, from an economic point of view, to be more sustainable. The active civic action has pushed the municipal administration to support the acquisition costs and operating costs [149-151]. This civic action has activated a solidarity campaign that has led some individuals, a bank, the major commercial centres, and a group of shops in the $S$. Vigo street (a road of about $1.5 \mathrm{~km}$ ) and the surrounding areas to make donations to support the transformation of Area 1. The level of civic support was very high, as evidenced by the percentage of households to which the questionnaires were administered. In total, for all the neighbourhoods that are interested by the transformation of Area 1, the support was: 60\% Piazza Carmine, 50\% San Martino, 50\% San Michele, $60 \%$ Tupparello, $40 \%$ Via Mandorle, and $40 \%$ Stazione Vecchia; this percentage relative to the first survey has been confirmed and even increased in the second survey, namely, that relating to the project chosen for the area. The experience that has been conducted yielded positive results in terms of the level of civic participation in the urban planning process. The general methodology may also support, with appropriate changes (such as the introduction of an equalising practice) the transformation of Area 2. The proposed methodology, with appropriate modifications, could be applied for the redevelopment of other urban residual green urban areas of the city of Acireale and, indeed, other urban contexts too.

The analysis was conducted in the pre-Covid-19 period, due to the spread of the Pandemic still the redevelopment interventions of Area 1 have not started.

As a result of this, the communities of the neighbourhoods involved in this project have expressed strong dissent for the unavailability of this space, which, although small, could support the few outdoor activities that could be carried out in areas close to their homes due to the restrictions imposed.

The Pandemic has increased the awareness of the communities, of the different neighbourhoods of the municipality of Acireale, of the importance of green areas close to their homes, highlighting their growing demand and affirming a vision of residual green urban areas as opportunities to reallocate it.

Funding: This work was financed by the University of Catania in a project entitled Architettura a Rischio: Demolire, Recuperare, Restaurare. Il tema della qualità nel progetto sul patrimonio- 
ARDeRe, scientific responsible De Medici S., which is part of the general project "Piano della Ricerca Dipartimentale 2020-2022 of the Department of Civil Engineering and Architecture".

Data Availability Statement: Not applicable.

Conflicts of Interest: The authors declare no conflict of interest.

\section{References}

1. Giuffrida, S. City as Hope. Valuation Science and the Ethics of Capital. Green Energy and Technology; Springer: Berlin/Heidelberg, Germany, 2018; pp. 469-485, ISSN 1865-3529. [CrossRef]

2. Nor, A.N.M.; Corstanje, R.; Harris, J.A.; Brewer, T. Impact of rapid urban expansion on green space structure. Ecol. Indic. 2017, 81, 274-284. [CrossRef]

3. Arnott, R.J.; Stiglitz, J.E. Aggregate Land Rents, Expenditure on Public Goods, and Optimal City Size. Q. J. Econ. 1979, $93,471$. [CrossRef]

4. Giuffrida, S.; Trovato, M.R.; Falzone, M. The information value for territorial and economic sustainability in the enhancement of the water management process. In Computational Science and Its Applications_ICCSA 2017. Lecture Notes in Computer Science; Borruso, G., Cuzzocrea, A., Apduhan, B.O., Rocha, A.M.A.C., Taniar, D., Misra, S., Gervasi, O., Torre, C.M., Stankova, E., Murgante, B., Eds.; Springer: Cham, Switzerland, 2017; Volume 10406, pp. 575-590. [CrossRef]

5. Zube, E. Perceived land Use Patterns and Landscape Values. Landsc. Ecol. 1987, 1, 37-45. [CrossRef]

6. Gehl, J. Life between Buildings: Using Public Space, 6th ed.; Island Press: Washington, DC, USA, 2011.

7. Trovato, M.; Clienti, C.; Giuffrida, S. People and the City: Urban Fragility and the Real Estate-Scape in a Neighborhood of Catania, Italy. Sustainability 2020, 12, 5409. [CrossRef]

8. Prigogine, E. Le Strutture Dissipative. Auto Organizzazione Dei Sistemi Termodinamici Di Non Equilibrio; Sansoni: Firenze, Italy, 1982.

9. Giuffrida, S.; Ventura, V.; Trovato, M.R.; Napoli, G. Axiology of the historical city and the cap rate the case of the old town of Ragusa superior. Valori E Valutazioni 2017, 18, 41-55, ISSN 20362404.

10. Trovato, M.R. A multi-criteria approach to support the retraining plan of the Biancavilla's old town. In New Metropolitan Perspectives, Proceedings of the 3rd International New Metropolitan Perspectives. Local Knowledge and Innovation Dynamics towards Territory Attractiveness through the Implementation of Horizon/Europe2020/Agenda2030, Reggio Calabria, Italy, 22-25 May 2018; Bevilacqua, C., Calabro, F., Della Spina, L., Eds.; Smart Innovation, Systems and Technologies; Springer: Cham, Switzerland, 2019; Volume 101, pp. 434-441. [CrossRef]

11. Napoli, G.; Giuffrida, S.; Trovato, M.R. A Paradigm Interpreting the City and the Analytic Network Process for the Management of Urban Transformations. In New Metropolitan Perspectives, Proceedings of the Smart Innovation, Systems and Technologies, 3rd International New Metropolitan Perspectives. Local Knowledge and Innovation Dynamics towards Territory Attractiveness through the Implementation of Horizon/Europe2020/Agenda2030, Reggio Calabria, Italy, 22-25 May 2018; Bevilacqua, C., Calabrò, F., Della Spina, L., Eds.; Springer Science and Business Media Deutschland GmbH: Cham, Switzerland, 2019; Volume 100, pp. 672-680. [CrossRef]

12. Capozza, D.R.; Helsley, R.W. The stochastic city. J. Urban Econ. 1990, 28, 187-203. [CrossRef]

13. Camagni, R.; Capello, R.; Nijkamp, P. Towards sustainable city policy: An economy-environment technology nexus. Ecol. Econ. 1998, 24, 103-118. [CrossRef]

14. Warziniack, T. Efficiency of public goods provision in space. Ecol. Econ. 2010, 69, 1723-1730. [CrossRef]

15. Wu, J.; Plantinga, A.J. The influence of public open space on urban spatial structure. J. Environ. Econ. Manag. 2003, 46, 288-309. [CrossRef]

16. Yang, C.H.; Fujita, M. Urban Spatial Structure with Open Space. Environ. Plan. A Econ. Space 1983, 15, 67-84. [CrossRef]

17. UNFCCC. Rapporto Della Conferenza Delle Nazioni Unite Sull'ambiente E Lo Sviluppo; UNFCCC: Rio de Janeiro, Brazil, 1992.

18. European Commission (COM2005/718). Strategia Tematica per L'ambiente Urbano; European Commission: Bruxelles, Belgium, 2005.

19. Giuffrida, S.; Trovato, M.R. A Semiotic Approach to the Landscape Accounting and Assessment. An Application to the UrbanCoastal Areas. In Information and Communication Technologies in Modern Agricultural Development, Proceedings of the 8th International Conference on Information and Communication Technologies in Agriculture, Food and Environment, HAICTA 2017, Chania, Crete Island, Greece, 21-24 September 2017; Salampasis, M., Theodoridis, A., Bournaris, T., Eds.; CEUR Workshop Proceedings: Aachen, Germany, 2017; Volume 2030, pp. 696-708, ISSN: 16130073.

20. Giuffrida, S.; Trovato, M.R.; Giannelli, A. Semiotic-Sociological Textures of Landscape Values. Assessments in Urban-Coastal Areas. In Information and Communication Technologies in Modern Agricultural Development, Proceedings of the 8th International Conference HAICTA 2017, Chania, Crete, Greece, 21-24 September 2017; Salampasis, M., Bournaris, T., Eds.; Communications in Computer and Information Science; Springer: Cham, Switzerland, 2019; Volume 953, pp. 35-50. [CrossRef]

21. Giuffrida, S.; Trovato, M.R. From the Object to Land. Architectural Design and Economic Valuation in the Multiple Dimensions of the Industrial Estates. In Computational Science and Its Applications-ICCSA 2017. Lecture Notes in Computer Science; Borruso, G., Cuzzocrea, A., Apduhan, B.O., Rocha, A.M.A.C., Taniar, D., Misra, S., Gervasi, O., Torre, C.M., Stankova, E., Murgante, B., Eds.; Springer: Cham, Switzerland, 2017; Volume 10406, pp. 591-606. [CrossRef]

22. Participants at the European Cities \& Towns towards Sustainability. Aalborg Charter. Aalborg, Denmark. 1994. Available online: https:/ / sustainablecities.eu/fileadmin/repository/Aalborg_Charter/Aalborg_Charter_English.pdf (accessed on 2 April 2019). 
23. European Local Governments. Aalborg Commitments. Aalborg, Denmark. 2004. Available online: https:/ / sustainablecities.eu/ fileadmin/repository/Aalborg_Commitments/Aalborg_Commitments_English.pdf (accessed on 2 April 2019).

24. Frumkin, H.; Bratman, G.N.; Breslow, S.J.; Cochran, B.; Kahn, P.H., Jr.; Lawler, J.J.; Levin, P.S.; Tandon, P.S.; Varanasi, U.; Wolf, K.L.; et al. Nature Contact and Human Health: A Research Agenda. Environ. Health Perspect. 2017, 125, 075001. [CrossRef]

25. Grahn, P.; Stigsdotter, U.A.; Berggren-Barring, A.M. A planning model for designing sustainable and healthy cities. The importance of people's need of recreational environments in an urban context. In Proceedings of the NAEP (National Assoc. of Environmental 372 Professionals) 30th Annual Conference, Alexandris, VA, USA, 16-19 April 2005.

26. Heidt, V.; Neef, M. Benefits of urban green space for improving urban climate. In Ecology, Planning, and Management of Urban Forests; Carreiro, M.M., Song, Y.C., Wu, J., Eds.; Springer: New York, NY, USA, 2008.

27. Coenen, F. Local agenda 21: 'Meaningful and effective' participation? In Public Participation and Better Environmental Decisions; Coenen, F.H.J.M., Ed.; Springer: Dordrecht, The Netherlands, 2009; pp. 165-182.

28. Kaplan, R.; Kaplan, S.; Ryan, R.L. With People in Mind. Design and Management of Everyday Nature; Island Press: Washington, DC, USA, 1998.

29. Sancassinani, W. Local Agenda 21 in Italy: An effective governance tool for facilitating local communities' participation and promoting capacity building for sustainability. Local Environ. 2005, 10, 189-200. [CrossRef]

30. ICLEI. Local Governments for Sustainability. 2008. Available online: https://southasiaoffice.iclei.org/\#: \{ \{\}:text=ICLEI\%20\%2 0Local $\% 20$ Governments $\% 20$ for $\% 20$ Sustainability $\% 20$ is $\% 20$ a,low $\% 20$ emission $\% 2 C \%$ 20nature-based $\% 2 C \% 20$ equitable $\% 2$ C $\%$ 20resilient\%20and\%20circular\%20development (accessed on 10 April 2021).

31. EU. Toledo Informal Ministerial Meeting on Urban Development Declaration (Toledo Declaration). 2010. Available online: http://urban-intergroup.eu/wp-content/file_mf/es2010itoledodeclaration.pdf (accessed on 10 April 2021).

32. Council of European Municipalities and Regions (CEMR) 16 Dicembre 2015. Available online: https:/ / ec.europa.eu/health/ sites/default/files/nutrition_physical_activity/docs/ev_20151216_co07_en.pdf (accessed on 10 April 2021).

33. EU. Leipzig Charter on Sustainable European Cities. 2007. Available online: https://ec.europa.eu/regional_policy/archive/ themes/urban/leipzig_charter.pdf (accessed on 20 January 2021).

34. EU. Informal Meeting of Ministers Responsible for Territorial Cohesion and Urban Matters Declaration of Ministers towards the EU Urban Agenda. 2015. Available online: https:/ / ec.europa.eu/futurium/en/system/files/ged/riga-declaration.pdf (accessed on 10 April 2021).

35. United Nations. The 2030 Agenda for Sustainable Development. 2015. Available online: http://sdps.un.org/goals (accessed on 2 April 2019).

36. EU. Urban Agenda for the EU Pact of Amsterdam. 2016. Available online: https://ec.europa.eu/regional_policy/sources/ policy/themes/urban-development/agenda/pact-of-amsterdam.pdf (accessed on 10 April 2021).

37. EU. The New Leipzig Charter. The Transformative Power of Cities for the Common Good. 2020. Available online: https: / / ec.europa.eu/regional_policy/en/newsroom/news/2020/12/12-08-2020-new-leipzig-charter-the-transformative-powerof-cities-for-the-common-good (accessed on 10 April 2021).

38. Pascual, U.; Balvanera, P.; Díaz, S.; Pataki, G.; Roth, E.; Stenseke, M.; Kelemen, E. Valuing nature's contributions to people: The IPBES approach. Curr. Opin. Environ. Sustain. 2017, 26, 7-16. [CrossRef]

39. Nesbitt, L.; Meitner, M.J.; Girling, C.; Sheppard, S.R.; Lu, Y. Who has access to urban vegetation? A spatial analysis of distributional green equity in 10 US cities. Landsc. Urban Plan. 2019, 181, 51-79. [CrossRef]

40. Mitchell, D. The Right to the City: Social Justice and the Fight for Public Space; Guilford: New York, NY, USA, 2003.

41. Arnberger, A. Urban Densification and Recreational Quality of Public Urban Green Spaces-A Viennese Case Study. Sustainability 2012, 4, 703-720. [CrossRef]

42. Rajapaksa, D.; Wilson, C.; Hoang, V.-N.; Lee, B.; Managi, S. Who responds more to environmental amenities and dis-amenities? Land Use Policy 2017, 62, 151-158. [CrossRef]

43. CABE Commission for Architecture and the Built Environment 2010, Community Green: Using Local Spaces to Tackle Inequality and Improve Health, London. 2010. Available online: https//www.designcouncil.org.uk/sites/default/files/asset/document/ community-green-full-report.pdf (accessed on 25 March 2021).

44. Cities. Special issue: Green cities. Cities 1996, 13, 303-372.

45. Sharp, R.; Douglass, J.; Wolny, S.; Arkema, K.K.; Bernhardt, J.; Bierbower, W.; Wyatt, K. InVEST 3.8.7 User's Guide. The Natural Capital Project. 2020. Available online: http://data.naturalcapitalproject.org/nightly-build/invest-users-guide/html/\# (accessed on 2 March 2019).

46. Burby, R.J. Making Plans that Matter:Citizen Involvement and Government Action. J. Am. Plan. Assoc. 2003, 69, 33-49. [CrossRef]

47. Coenen, F. Participation in strategic green planning in the Netherlands. In Participation and the Quality of Environmental Decision Making; Coenen, F., Huitema, D., O'Toole, L., Eds.; Kluwer: Dordrecht, The Netherlands, 1998.

48. TEEB. The Economics of Ecosystems and Biodiversity: Ecological and Economic Foundation; Earthscan: Cambridge, UK, 2010.

49. Schindler, M.; Le Texier, M.; Caruso, G. Spatial sorting, attitudes and the use of green space in Brussels. Urban For. Urban Green. 2018, 31, 169-184. [CrossRef]

50. M. D. n. 1444/68. (G. U. 16th April 1968, n. 97). Available online: https://www.camera.it/temiap/2014/12/09/OCD177-705.pdf (accessed on 2 March 2019). 
51. Trovato, M.R. Human Capital Approach in the Economic Assessment of Interventions for the Reduction of Seismic Vulnerability in Historic Centres. Sustainability 2020, 12, 8059. [CrossRef]

52. Goulder, L.H.; Kennedy, D. Valuating Ecosystem services: Philosophical based and empirical methods. In Nature's Services; Daily, G.C., Ed.; Island Press: Washington, DC, USA, 1997.

53. Daily, G.C. Nature's Services. Societal Dependence on Natural Ecosystems; Gretchen, C., Ed.; Island Press: Washington, DC, USA, 1997.

54. Daily, H.E.; Farley, J. Ecological Economics: Principles and Applications; Island Press: Washington, DC, USA, 2004.

55. Farber, S.C.; Costanza, R.; Wilson, M.A. Economic and ecological concepts for valuing ecosystem services. Ecol. Econ. 2002, 41, 375-392. [CrossRef]

56. Tzoulas, K.; Korpela, K.; Venn, S.; Yli-Pelkonen, V.; Kaźmierczak, A.; Niemela, J.; James, P. Promoting ecosystem and human health in urban areas using Green Infrastructure: A literature review. Landsc. Urban Plan. 2007, 81, 167-178. [CrossRef]

57. Daily, G.C.; Matson, P.A. Ecosystem services: From theory to implementation. Proc. Nat. Acad. Sci. USA 2008, 105, 9455-9456, ISSN 2036-2404.

58. Costanza, R. Ecosystem services: Multiple classification systems are needed. Biol. Conserv. 2008, 141, 350-352. [CrossRef]

59. Giuffrida, S.; Trovato, M.R.; Circo, C.; Ventura, V.; Giuffrè, M.; Macca, V. Seismic Vulnerability and Old Towns. A Cost-Based Programming Model. Geosciences 2019, 9, 427. [CrossRef]

60. Baró, F.; Palomo, I.; Zulian, G.; Vizcaino, P.; Haase, D.; Gómez-Baggethun, E. Mapping ecosystem service capacity, flow and demand for landscape and urban planning: A case study in the Barcelona metropolitan region. Land Use Policy 2016, 57, 405-417. [CrossRef]

61. Cortinovis, C.; Geneletti, D. Ecosystem services in urban plans: What is there, and what is still needed for better decisions. Land Use Policy 2018, 70, 298-312. [CrossRef]

62. Costanza, R.; Folke, C. Valuating Ecosystem services with efficiency, fairness and sustainability as goals. In Nature's Services; Daily, G.C., Ed.; Island Press: Washington, DC, USA, 1997.

63. Geneletti, D.; Esmail, B.A.; Cortinovis, C.; Arany, I.; Balzan, M.; Van Beukering, P.; Bicking, S.; Borges, P.; Borisova, B.; Broekx, S.; et al. Ecosystem services mapping and assessment for policy- and decision-making: Lessons learned from a comparative analysis of European case studies. One Ecosyst. 2020, 5, e53111. [CrossRef]

64. Gómez-Baggethun, E.; Barton, D.N. Classifying and valuing ecosystem services for urban planning. Ecol. Econ. 2013, 86, 235-245. [CrossRef]

65. Millennium Ecosystem Assessment. Ecosystems and Human Well-Being: Synthesis; Island Press: Washington, DC, USA, 2005; Available online: https:/ / www.millenniumassessment.org/en/Synthesis.html (accessed on 2 March 2019).

66. Haase, D.; Larondelle, N.; Andersson, E.; Artmann, M.; Borgström, S.; Breuste, J.; Hansen, R. A quantitative review of urban ecosystem service assessments: Concepts, models, and implementation. Ambio 2014, 43, 413-433. [CrossRef]

67. Keeler, B.L.; Hamel, P.; McPhearson, T.; Hamann, M.H.; Donahue, M.L.; Prado, K.A.M.; Finlay, J.C. Social-ecological and technological factors moderate the value of urban nature. Nat. Sustain. 2019, 2, 29-38. [CrossRef]

68. Giuffrida, S.; Casamassima, G.; Trovato, M.R. Le norme EMAS-ISO nella valutazione della qualità del servizio idrico integrato. Aestimum 2017, 70, 109-134. [CrossRef]

69. Nelson, E.; Mendoza, G.; Regetz, J.; Polasky, S.; Tallis, H.; Cameron, D.; Chan, K.; Daily, G.C.; Goldstein, J.; Kareiva, P.M.; et al. Modeling multiple ecosystem services, biodiversity conservation, commodity production, and tradeoffs at landscape scales. Front. Ecol. Environ. 2009, 7, 4-11. [CrossRef]

70. Marando, F.; Salvatori, E.; Sebastiani, A.; Fusaro, L.; Manes, F. Regulating Ecosystem Services and Green Infrastructure: Assessment of Urban Heat Island effect mitigation in the municipality of Rome, Italy. Ecol. Model. 2019, 392, 92-102. [CrossRef]

71. Liquete, C.; Kleeschulte, S.; Dige, G.; Maes, J.; Grizzetti, B.; Olah, B.; Zulian, G. Mapping green infrastructure based on ecosystem services and ecological networks: A Pan-European case study. Environ. Sci. Policy 2015, 54, 268-280. [CrossRef]

72. Guerry, A.D.; Polasky, S.; Lubchenco, J.; Chaplin-Kramer, R.; Daily, G.C.; Griffin, R.; Elmqvist, T. Natural capital and ecosystem services informing decisions: From promise to practice. Proc. Natl. Acad. Sci. USA 2015, 112, 7348-7355. [CrossRef]

73. Pearce, D.W.; Howarth, A. Technical Report on Methodology: Cost Benefit Analysis and Policy Responses. RIVM Report 481505020. 2020. Available online: http:/ / www.rivm.nl/bibliotheek/rapporten/481505020.pdf (accessed on 2 March 2019).

74. Pearce, D.W. Economic Values and the Natural World; MIT Press: Cambridge, UK, 1993.

75. Costanza, R.; d'Arge, R.; de Groot, R.; Farber, S.; Grasso, M.; Hannon, B.; Limburg, K.; Naeem, S.; O’Neill, R.V.; Paruelo, J.; et al. The value of the world's ecosystem services and natural capital. Nature 1997, 387, 253-260. [CrossRef]

76. Trovato, M.R.; Giuffrida, S. The Monetary Measurement of Flood Damage and the Valuation of the Proactive Policies in Sicily. Geosciences 2018, 8, 141. [CrossRef]

77. Trovato, M.R.; Giuffrida, S. The Protection of Territory from the Perspective of the Intergenerational Equity. In Integrated Evaluation for the Management of Contemporary Cities; Mondini, G., Fattinnanzi, E., Oppio, A., Bottero, M., Stanghellini, S., Eds.; SIEV 2016, Green Energy and Technology; Springer Nature Switzerland AG: Cham, Switzerland, 2018; pp. 46-485. [CrossRef]

78. Saphores, J.D.; Li, W. Estimating the value of urban green areas: A hedonic pricing analysis of the single family housing market in Los Angeles, CA. Landsc. Urban Plan. 2012, 104, 373-387. [CrossRef]

79. Ham, C.; Champ, P.A.; Loomis, J.B.; Reich, R.M. Accounting for heterogeneity of public lands in hedonic property models. Land Econ. 2012, 88, 444-456. [CrossRef] 
80. Gibbons, S.; Mourato, S.; Resende, G.M. The amenity value of english nature: A hedonic price approach.Environ. Resour. Econ. 2014, 57, 175-196. [CrossRef]

81. Anderson, S.T.; West, S.E. Open space, residential property values, and spatial context. Reg. Sci. Urban Econ. 2006, 36, 773-789. [CrossRef]

82. Sabyrebekov, R.; Dallimer, M.; Navrud, S. Nature affinity and willingness to pay for urban green spaces in a developing country. Landsc. Urban Plan. 2020, 194, 103700. [CrossRef]

83. Evenson, K.R.; Wen, F.; Golinelli, D.; Rodriguez, D.A.; Cohen, D.A. Measurement properties of a park use questionnaire. Environ. Behav. 2013, 45, 526-547. [CrossRef]

84. Turner, M. Landscape preferences and patterns of residential development. J. Urban Econ. 2005, 57, 19-54. [CrossRef]

85. Bottero, M. The economic value of landscape: An application for a rural area in Northern Italy. In Landscape Planning and Rural Development C; Rega, C., Ed.; Springer: Berlin, Germany, 2014; pp. 89-104. [CrossRef]

86. Bottero, M. A multi-methodological approach for assessing sustainability of urban projects. Manag. Environ. Qual. Int. J. 2015, 26, 138-154. [CrossRef]

87. Chen, B.; Qi, X. Protest response and contingent valuation of an urban forest park in Fuzhou City, China. Urban For. Urban Green. 2018, 29, 68-76. [CrossRef]

88. Maltese, I.; Mariotti, I.; Oppio, A.; Boscacci, F. Assessing the benefits of slow mobility connecting a cultural heritage. J. Cult. Herit. 2017, 26, 153-159. [CrossRef]

89. Oppio, A.; Bottero, M.; Ferretti, V. Designing adaptive reuse strategies for cultural heritage with choice experiments. In Appraisal: From Theory to Practice; Stanghellini, S., Morano, P., Bottero, M., Oppio, A., Eds.; Springer Nature Switzerland AG: Cham, Switzerland, 2017; pp. 303-315. [CrossRef]

90. Berta, M.; Bottero, M.; Ferretti, V. A mixed methods approach for the integration of urban design and economic evaluation: Industrial heritage and urban regeneration in China. Environ. Plan. B Plan. Des. 2016, 45, 208-232. [CrossRef]

91. Mitchell, R.C.; Carson, R.T. Using Surveys to Value Public Goods. The Contingent Valuation Method, Washington DC; Resources for the Future: Washington, DC, USA, 1989.

92. Ciriacy-Wantrup, S.V. Capital returns from soil conservation practices. Am. J. Agric. Econ. 1947, 29, 1181-1196. [CrossRef]

93. Stander, L.; Theodore, L. Environmental Regulatory Calculations Handbook; John Wiley and Sons, Inc.: Hoboken, NJ, USA, 2006. [CrossRef]

94. Gramling, R.; Freudenburg, W.R. The Exxon Valdez oil spill in the context of US petroleum politics. Organ. Environ. 1992, 6, 175-196. [CrossRef]

95. Arrow, K.; Solow, R.; Portney, P.R.; Leamer, E.E.; Radner, R.; Schuman, H. National Oceanic and Atmospheric Administration. Report of the NOAA Panel on Contingent Valuation. 1993. Available online: https:/ / edisciplinas.usp.br/pluginfile.php/502137 9/mod_resource/content/0/Arow_WTP.pdf (accessed on 2 March 2019).

96. Stellin, G.; Rosato, P. La Valutazione Economica Dei Beni Ambientali. Metodologia e Casi Di Studio; Cittàstudi: Torino, Italy, 1998.

97. Halkos, G.; Leonti, A.; Sardianou, E. Assessing the Preservation of Parks and Natural Protected Areas: A Review of Contingent Valuation Studies. Sustainability 2020, 2, 4784. [CrossRef]

98. Pearce, D.W.; Turner, R.K. Economics of Natural Resources and the Environment; Johns Hopkins University Press: Baltimore, MD, USA, 1990. [CrossRef]

99. Bateman, I.J.; Carson, R.T.; Day, B.; Hanemann, M.; Hanley, N.; Hett, T.; Jones-Lee, M.; Loomes, G.; Mourato, S.; Ozdemiroglu, E.; et al. Economic Valuation with Stated Preference Techniques: A Manual; Edward Elgar, Ltd.: Cheltenham, UK, $2002 ;$ ISBN 1840649194.

100. Tempesta, T.; Marangon, F. Stima del valore economico totale dei paesaggi forestali italiani tramite valutazione contingente. Genio Rurale Estimo Territ. 2004, 11, 32-45.

101. Giannelli, A.; Giuffrida, S.; Trovato, M.R. Madrid Rio Park. Symbolic Values and Contingent Valuation. Valori Valutazioni 2018, 21, 75-85, E-Flow Dei Tipografia del Genio CivileISSN 20362404.

102. Naselli, F.; Trovato, M.R.; Castello, G. An evaluation model for the actions in supporting of the environmental and landscaping rehabilitation of the Pasquasia's site mining (EN). In Computational Science and Its Applications_ICCSA 2014. LNCS, 8581 (III); Murgante, B., Misra, S., Rocha, A.M.A.C., Torre, C.M., Rocha, J.G., Falcão, M.I., Taniar, D., Apduhan, B.O., Gervasi, O., Eds.; Springer International Publishing Switzerland: Cham, Switzerland, 2014; pp. 26-41. [CrossRef]

103. Trovato, M.R.; Giuffrida, S. A DSS to Assess and Manage the Urban Performances in the Regeneration Plan: The Case Study of Pachino. In International Conference on Computational Science and Its Applications-ICCSA 2014, LNCS 8581, Part III; Murgante, B., Misra, S., Rocha, A.M.A.C., Torre, C.M., Rocha, J.G., Falcão, M.I., Taniar, D., Apduhan, B.O., Gervasi, O., Eds.; Springer Nature Switzerland AG: Cham, Switzerland, 2014; pp. 224-239. [CrossRef]

104. Trovato, M.R.; Giuffrida, S. The choice problem of the urban performances to support the Pachino's redevelopment plan. Int. J. Bus. Intell. Data Min. 2014, 9, 330. [CrossRef]

105. Giuffrida, S.; Gagliano, F.; Giannitrapani, E.; Marisca, C.; Napoli, G.; Trovato, M.R. Promoting Research and Landscape Experience in the Management of the Archaeological Networks. A Project-Valuation Experiment in Italy. Sustainability 2020, 12, 4022. [CrossRef]

106. European Commission (COM 2004/327). Green Paper; European Commission: Bruxelles, Belgium. 
107. Italian Government. L. D. No. 179/2012 (Converted into Law on 17th December 2012, No. 221). Rome, Italy. Available online: https://www.gazzettaufficiale.it/atto/serie_generale/caricaDettaglioAtto/originario?atto.dataPubblicazioneGazzetta= 2012-12-18\&atto.codiceRedazionale=12A13277 (accessed on 2 March 2019).

108. Consob. Crowdfunding Regulation 2013; Resolution No. 18592/2013; Consob: Rome, Italy, 2013.

109. Barollo, A.; Castrataro, D. Il Crowdfunding Civico, Una Proposta, Italy. 2013. Available online: https://issuu.com/alessiobarollo/ docs / civic-crowdfunding (accessed on 2 March 2019).

110. Maron, D.; Lawton, K. The Crowdfunding Revolution; McGraw-Hill: Milano, Italy, 2010.

111. Sicily Region Law, Reorganization of Social Welfare Services and Activities in Sicily 9 May 1986, n. 22 (in Gazz.Uff. of Sicily, 10 May, n. 23). Available online: https://www.regione.sicilia.it/lavoro/uffici/agimp/hand/Ricerca/Leg022.htm (accessed on 2 March 2019).

112. Giuffrida, S.; Ventura, V.; Nocera, F.; Trovato, M.R.; Gagliano, F. Technological, Axiological and Praxeological Coordination in the Energy-Environmental Equalization of the Strategic Old Town Renovation Programs. In Values and Functions for Future Cities, Part of Green energy and technology; Mondini, G., Oppio, A., Stanghellini, S., Bottero, M., Abastante, F., Eds.; Springer Nature Switzerland AG: Cham, Switzerland, 2020; pp. 425-446. [CrossRef]

113. Giuffrida, S.; Carocci, C.; Circo, C.; Giuffrè, M.; Trovato, M.R.; Ventura, V. Axiological strategies in the old towns seismic vulnerability mitigation planning. Valori Valutazioni Dei Tipografia Genio Civile 2020, 25, 99-106, ISSN: 20362404.

114. Auckland Council. Parks and Open Spaces Strategic Action Plan. 2013. Available online: https://www.aucklandcouncil.govt. nz/plans-projects-policies-reports-bylaws/our-plans-strategies/topic-based-plans-strategies/parks-sports-outdoor-plans / Documents/parks-open-spaces-strategic-action-plan.pdf (accessed on 1 April 2021).

115. Auckland Council. Open Space Strategic Asset Management Plan 2015-2025. 2015. Available online: https:/ /www.aucklandcouncil. govt.nz/plans-projects-policies-reports-bylaws/our-plans-strategies/topic-based-plans-strategies/docsassetmanagementplan/ open-space-strategic-asset-management-plan.pdf (accessed on 1 April 2021).

116. Auckland Council. Housing Supply and Special Housing Areas. 2017. Available online: http:/ /www.aucklandcouncil.govt.nz/ EN/ratesbuildingproperty/housingsupply/Pages/specialhousingareas.aspx (accessed on 1 April 2021).

117. Auckland Council. National Policy Statement on Urban Development Capacity2016: Housing and Business Development Capacity Assessment for Auckland. 2017. Available online: http:/ / www.knowledgeauckland.org.nz/assets/publications/NPSUDC-Housing-and-business-development-capacity-assessment-for-Auckland-Dec2017.pdf (accessed on 2 March 2019).

118. Auckland Council. Auckland Unitary Plan. 2018. Available online: http://unitaryplan.aucklandcouncil.govt.nz/Pages/Plan/ Book.aspx?exhibit=AucklandUnitaryPlan_Print (accessed on 1 April 2021).

119. Ayala-Azcárraga, C.; Diaz, D.; Zambrano, L. Characteristics of urban parks and their relation to user well-being. Landsc. Urban Plan. 2019, 189, 27-35. [CrossRef]

120. Cho, S.-H.; Poudyal, N.C.; Roberts, R.K. Spatial analysis of the amenity value of green open space. Ecol. Econ. 2008, 66, 403-416. [CrossRef]

121. Conway, D.; Li, C.Q.; Wolch, J.; Kahle, C.; Jerrett, M. A Spatial Autocorrelation Approach for Examining the Effects of Urban Greenspace on Residential Property Values. J. Real Estate Finance Econ. 2008, 41, 150-169. [CrossRef]

122. Gabrielli, L.; Giuffrida, S.; Trovato, M.R. Real estate landscapes and the historic city: On how looking inside the market. In New Metropolitan Perspectives, Proceedings of the Smart Innovation, Systems and Technologies, 3rd International New Metropolitan Perspectives. Local Knowledge and Innovation Dynamics Towards Territory Attractiveness through the Implementation of Horizon/Europe2020/Agenda2030, Reggio Calabria, Italy, 22-25 May 2018; Bevilacqua, C., Calabrò, F., Della Spina, L., Eds.; Springer Science and Business Media Deutschland GmbH: Cham, Switzerland, 2019; Volume 101, pp. 269-276. [CrossRef]

123. Napoli, G.; Giuffrida, S.; Trovato, M.R.; Valenti, A. Cap Rate as the Interpretative Variable of the Urban Real Estate Capital Asset: A Comparison of Different Sub-Market Definitions in Palermo, Italy. Buildings 2017, 7, 80. [CrossRef]

124. Gabrielli, L.; Giuffrida, S.; Trovato, M.R. Gaps and Overlaps of Urban Housing Sub Market: A Fuzzy Clustering Approach. In Appraisal from Theory to Practice, Green Energy and Technology; Stanghellini, S., Morano, P., Bottero, M., Oppio, A., Eds.; Springer Nature Switzerland AG: Cham, Switzerland, 2017; pp. 203-219, Issue 9783319496757. [CrossRef]

125. Gabrielli, L.; Giuffrida, S.; Trovato, M.R. From Surface to Core: A Multi-layer Approach for the Real Estate Market Analysis of a Central Area in Catania. In Computational Science and Its Applications-ICCSA 2015, LCNS 9157; Gervasi, O., Murgante, B., Misra, S., Gavrilova, M.L., Rocha, A.M.A.C., Torre, C.M., Taniar, D., Apduhan, B.O., Eds.; Springer Nature Switzerland AG: Cham, Switzerland, 2015; Volume III, pp. 284-300. [CrossRef]

126. Gabrielli, L.; Giuffrida, S.; Trovato, M.R. Functions and Perspectives of Public Real Estate in the Urban Policies: The Sustainable Development Plan of Syracuse. In Computational Science and Its Applications_ICCSA 2016, LNCS 9789; Gervasi, O., Murgante, B., Misra, S., Rocha, A.M.A.C., Torre, C.M., Taniar, D., Apduhan, B.O., Stankova, E., Wang, S., Eds.; Springer Nature Switzerland AG: Cham, Switzerland, 2016; Volume IV, pp. 13-28. [CrossRef]

127. Assessorato Regionale Delle Infrastrutture e Della Mobilità. Prezziario della Regione Sicilia. 2019. Available online: http: //pti.regione.sicilia.it/portal/page/portal/PIR_PORTALE/PIR_LaStrutturaRegionale/PIR_AssInfrastruttureMobilita/PIR_ Diptecnico/PIR_Areetematiche/PIR_CRLLPP-Prezziario/PIR_Prezzarioregionalenew/PIR_Prezzariovigente/Prezzario\%20 2019\%20corretto.pdf (accessed on 25 March 2019).

128. Napoli, G.; Giuffrida, S.; Trovato, M.R. Fair planning and affordability housing in urban policy. The case of Syracuse (Italy). In Computational Science and Its Applications_ICCSA 2016. Lecture Notes in Computer Science, 9789 (III); Gervasi, O., Apduhan, B.O., 
Taniar, D., Torre, C.M., Wang, S., Misra, S., Murgante, B., Stankova, E., Rocha, A.M.A.C., Eds.; Springer Nature Switzerland AG: Cham, Switzerland, 2016; pp. 46-62. [CrossRef]

129. Giuffrida, S.; Gagliano, F.; Trovato, M.R. Land as Information. A Multidimensional Valuation Approach for Slow Mobility Planning. In HAICTA, Proceedings of the 7th International Conference on Information and Communication Technologies in Agriculture, Food and Environment (HAICTA 2015); Kavala, Greece, 17-20 September 2015, Andreopoulou, Z., Bochtis, D., Eds.; CEUR Workshop Proceedings: Aachen, Germany, 2015; Volume 1498, pp. 879-891.

130. Harting, T.; Bringslimark, T.; Patil, G.G. Restorative Environmental Design: What, When, Where, and for Whom? In Biophilic Design: The Theory, Science, and Practice of Bringing Buildings to Life; Kellert, S., Heerwagen, J., Mador, M., Eds.; John Wiley and Sons: Hoboken, NJ, USA, 2008; pp. 133-341.

131. Trovato, M.R.; Nocera, F.; Giuffrida, S. Life-Cycle Assessment and Monetary Measurements for the Carbon Footprint Reduction of Public Buildings. Sustainability 2020, 12, 3460. [CrossRef]

132. Mohajerani, A.; Bakaric, J.; Jeffrey-Bailey, T. The urban heat island effect, its causes, and mitigation, with reference to the thermal properties of asphalt concrete. J. Environ. Manag. 2017, 197, 522-538. [CrossRef] [PubMed]

133. Nocera, F.; Giuffrida, S.; Trovato, M.R.; Gagliano, A. Energy and New Economic Approach for Nearly Zero Energy Hotels. Entropy 2019, 21, 639. [CrossRef] [PubMed]

134. Strohbach, M.W.; Arnold, E.; Haase, D. The carbon footprint of urban green space-A life cycle approach. Landsc. Urban Plan. 2012, 104, 220-229. [CrossRef]

135. Giuffrida, S.; Gagliano, F.; Nocera, F.; Trovato, M.R. Landscape Assessment and Economic Accounting in Wind Farm Programming: Two Cases in Sicily. Land 2018, 7, 120. [CrossRef]

136. Day, S. Place and the experience of air quality. Health Place 2020, 13, 249-260. [CrossRef]

137. Berliant, M.; Peng, S.-K.; Wang, P. Welfare analysis of the number and locations of local public facilities. Reg. Sci. Urban Econ. 2006, 36, 207-226. [CrossRef]

138. Zardo, L.; Geneletti, D.; Pérez-Soba, M.; Van Eupen, M. Estimating the cooling capacity of green infrastructures to support urban planning. Ecosyst. Serv. 2017, 26, 225-235. [CrossRef]

139. van den Bosch, M.; Sang, A.O. Urban natural environments as nature-based solutions for improved public health-a systematic review of reviews. Environ. Res. 2017, 158, 373-384. [CrossRef]

140. Walsh, R. Endogenous open space amenities in a locational equilibrium. J. Urban Econ. 2007, 61, 319-344. [CrossRef]

141. Lepofsky, J.; Fraser, J.C. Building Community Citizens: Claiming the Right to Place-making in the City. Urban Stud. 2003, 40, 127-142. [CrossRef]

142. Papparlardo, V.; La Rosa, D. Policies for sustainable drainage systems in urban contexts within performance-based planning approaches. Sustain. Cities Soc. 2020, 52, 101830. [CrossRef]

143. Kim, G. An integrated system of urban green infrastructure on different types of vacant land to provide multiple benefits for local communities. Sustain. Cities Soc. 2018, 36, 116-130. [CrossRef]

144. Keeney, R.L. Value-Focused Thinking: A Path to Creative Decision Making; Harvard University Press: Cambridge, UK, 1992.

145. Hendricks, M.D.; Meyer, M.A.; Gharaibeh, N.G.; Van Zandt, S.; Masterson, J.; Cooper, J.T.; Horney, J.A.; Berke, P. The development of a participatory assessment technique for infrastructure: Neighborhood-level monitoring towards sustainable infrastructure systems. Sustain. Cities Soc. 2018, 38, 265-274. [CrossRef]

146. Loh, C.G. Placemaking and implementation: Revisiting the performance principle. Land Use Policy 2019, 81, 68-75. [CrossRef]

147. Nicodemus, A.G. Fuzzy vibrancy: Creative placemaking as ascendant US cultural policy. Cult. Trends 2013, 22, 213-222. [CrossRef]

148. Cooper-Marcus, C.; Francis, C. People Places. Design Guidelines for Urban Open Space; John Wiley and Sons: New York, NY, USA, 1998.

149. Gregory, R.; Keeney, R.L. Creating Policy Alternatives Using Stakeholder Values. Manag. Sci. 1994, 40, 1035-1048. [CrossRef]

150. Napoli, G.; Giuffrida, S.; Trovato, M.R. Efficiency versus Fairness in the Management of Public Housing Assets in Palermo (Italy). Sustainability 2019, 11, 1190, ISSN 2071-1050. [CrossRef]

151. Trovato, M.; Micalizzi, P.; Giuffrida, S. Assessment of Landscape Co-Benefits in Natura 2000 Site Management Plans. Sustainability 2021, 13, 5707. [CrossRef] 